\title{
OS ENTRAVES JURÍDICOS OCASIONADOS PELO DIREITO E PELO ESTADO PARA A NÃO CONCRETIZAÇÃO DO DIREITO À MORADIA
}

\section{THE LEGAL OBSTACLES MADE BY THE LAW AND BY THE STATE FOR THE NON- ACHIEVEMENT OF THE RIGHT TO HOUSING}

\section{Diogo de Calasans Melo Andrade ${ }^{1}$}

\section{Resumo}

o objetivo do presente artigo é buscar quais são os entraves jurídicos que impedem a concretização do direito à moradia no Brasil. Para isso, analisou-se o Estatuto da Cidade e o Plano Diretor e, percebeu-se, que os mesmos não foram devidamente regulamentados, o que compromete a aplicação do princípio da função social da propriedade urbana e, consequentemente, a moradia. Por outro lado, detectou-se que as estratégias traçadas para reduzir o déficit habitacional, trazidas pelo Plano Nacional de Habitação e pela Política Nacional de Habitação, não foram incorporadas ao Programa Minha Casa Minha Vida (PMCMV). Na contramão, buscou-se as possíveis soluções marxistas para a escassez da moradia. Por fim, percebeu-se que os empreendimentos do PMCMV foram criados pelo Estado para satisfazer os interesses privados do setor financeiro e imobiliário, ocasionando, com isso, a segregação urbana e a mercantilização da moradia, além de consequências diretas para seus moradores e, indiretas, para toda a sociedade. Para tanto, tentou-se aplicar as teorias marxistas sobre moradia no PMCMV, utilizando-se, para tanto, teóricos estrangeiros e nacionais, além dados estatísticos coletados em pesquisas científicas sobre o tema, já realizadas anteriormente.

Palavras-chaves: instrumentos jurídicos; entraves à moradia; PMCMV; segregação; mercantilização.

\section{Abstract}

The objective of this article is to find out what are the legal obstacles to the realization of the right to housing in Brazil. For this, the City Statute and the Master Plan were analyzed and, it was realized, that they were not properly regulated, which compromises the application of the

\footnotetext{
1 Doutor em direito político e econômico pela Universidade Mackenzie. Professor universitário e pesquisar. E-mail: contato@diogocalasans.com
} 
principle of the social function of urban property and, consequently, housing. On the other hand, it was detected that the strategies designed to reduce the housing deficit brought by the National Housing Plan and the National Housing Policy were not incorporated into the "Minha Casa Minha Vida" (PMCMV) Program. Against that, the possible Marxist solutions for housing shortage were sought. Finally, it was noticed that PMCMV ventures were created by the State to satisfy the private interests of the financial and real estate sector, causing, with this, urban segregation and the commodification of housing, as well as direct consequences for its residents and, indirectly, for the whole society. In order to do so, it was tried to apply the Marxian theories on housing in the PMCMV, using, for that, foreign and national theorists, besides statistical data collected in scientific researches on the subject, already realized previously.

Keywords: legal instruments; obstacles towards housing; PMCMV; segregation; commodification. 


\section{INTRODUÇÃO}

Através do presente artigo buscou-se entender quais são os entraves jurídicos ao direito à moradia no Brasil. Para isso, compreendeu-se que o direito à moradia decorre da função social da propriedade urbana e é, ao mesmo tempo, um direito humano e fundamental, necessitando do Estado e do Direito para concretizar esse direito social, através de leis urbanísticas, que possibilitem a restrição da ocupação democrática da propriedade.

Para analisar os instrumentos urbanísticos, o primeiro instrumento jurídico estudado foi - Estatuto da Cidade, que disciplina o conteúdo da função social da propriedade urbana definindo as diretrizes da política urbana, tendo como instrumentos da política urbana o parcelamento, a edificação compulsória, o ITPU progressivo e a desapropriação. Buscou, detectar, através de pesquisas já realizadas anteriormente, se esses instrumentos urbanísticos são de fato aplicados pelos municípios do nosso país ou apenas simbólicos.

Analisou-se, também, o Plano Diretor, considerado instrumento de política de desenvolvimento e expansão urbana que tem como finalidade desenvolver a função social da propriedade urbana, estabelecendo dentro do plano quais são os requisitos para uma propriedade privada urbana atender à função social. Assim, buscou-se compreender se nos planos diretores são incorporados tais requisitos, para que se possa aplicar o princípio da função social da propriedade urbana e, consequentemente, a moradia.

Percebeu-se que o Plano Nacional de Habitação (PNH) possui uma ação conjunta do Sistema Nacional de Habitação, o Desenvolvimento Institucional, o Sistema de Informação e Avaliação e Monitoramento da Habitação, além do Política Nacional de Habitação (PlanHab). Esse PNH atua de duas formas, uma voltada à provisão de novas moradias e, outra, urbanizando os assentamentos precários; assim, seus eixos são a política fundiária, política financeira e estrutura institucional. Por fim, buscou-se entender se o objetivo do plano em planejar as ações públicas e privadas, durante 15 anos, para combater o déficit habitacional foi alcançado ou não.

Compreendeu-se a Política Nacional de Habitação (PlanHab), com suas ações públicas e privadas, no sentido de equacionar as necessidades habitacionais com base em quatro eixos: 0 financiamento, os arranjos institucionais, a cadeia produtiva da construção civil e as estratégias urbano fundiárias. Buscou-se, também, analisar se o Programa Minha Casa Minha Vida está ou não em consonância com as estratégias trazidas pelo PlanHab.

Nesse sentido, seria necessário fazer uma pesquisa científica específica, que não é o objetivo deste artigo, para perceber se o Programa Minha Casa Minha Vida acompanhou as 
diretrizes do Plano Nacional de Habitação. Entretanto, através da doutrina especialista no assunto procuramos identificar se o PMCMV adotou ou não o conjunto de estratégias que o PlanHab julga necessárias para diminuir o déficit habitacional no Brasil, como também se ignorou ou não as premissas e os debates em torno do plano.

Trouxemos, a forma jurídica moradia como reflexo da relação social, fixando um vínculo entre essa forma e a mercantil. Detectou-se que a escassez de moradia atingiu todas as classes em todos os tempos, sendo consequência direta da privação do trabalhador, resultado do aumento da concentração urbana e decorrente do modo de produção capitalista, buscando, através da doutrina, a "solução" para essa escassez.

Procurou-se, através da leitura marxista, a possível solução para pôr um fim na escassez da moradia. Percebeu-se que essa escassez decorre do atual modo de produção capitalista e, os problemas relativos à moradia, não são resolvidos, mas, somente, transferidos de um lugar para outro. Compreendeu-se o sentido e o alcança da moradia para Engels que defendia como solução para a questão da moradia a abolição do modo de produção capitalista, trazendo a ideia que a extinção do documento da propriedade (título de propriedade) é uma saída para a questão da falta de moradias.

Identificou-se que as invasões de terras apesar de ser ilegal, é institucional e funcional para a economia, mercado imobiliário e para os investimentos públicos, com o objetivo da extração da renda fundiária. Percebeu-se que as favelas se tornam a única alternativa para a falta de habitação e, nesse sentido, foi coletado dados estatísticos na doutrina especialista, para situar o Brasil em relação à população de vive da informalidade.

Buscou-se dados na Fundação João Pinheiro, relativos ao déficit habitacional, tendo como finalidade orientar as definições da política nacional de habitação, além de questionar a capacidade da fundação de mensurar a carência de habitações. Por outro lado, coletou-se, no Censo-IBGE, a quantidade de pessoas que vivem em aglomerados urbanos.

Detectou-se que, em virtude do enorme número do déficit habitacional no Brasil, além do grande número de pessoas que moram em aglomerados subnormais, o governo criou o Programa Minha Casa Minha Vida (PMCMV) com o intuito de reduzir esses dados. Para entender o programa compreendeu-se suas fases e faixas, sua finalidade, além de conhecer seus agentes, quais sejam, operador financeiro, as construtoras e o Município.

Identificamos que a política do programa se divide em, de um lado, subsídio público, à produção habitacional, para a população de baixa renda (em parceria com os municípios), com a utilização de investimentos públicos, operados pela Caixa e, em contrapartida, destinado à 
renda média, denominada, segmento econômico, os descontos, recursos onerosos do FGTS, redução de juros e acesso ao crédito.

Percebeu-se, que é de competência do Poder Público local a elaboração dos planos diretores e das leis de uso e ocupação do solo urbano, além da necessidade da participação do município no mercado de terras e, na escolha da localização do empreendimento, dessa forma, envolve-se com a instalação dos serviços de educação, saúde, lazer e transporte público. Assim, cabe ao município ofertar a terra urbanizada e bem localizada, além de estabelecer os instrumentos urbanísticos, infraestrutura, equipamentos e serviços.

Compreendeu-se a ligação entre a utilização dos fundos públicos e a construção das habitações pelo PMCMV, como também, suas consequências. Através das publicações dos resultados das pesquisas do "Observatório das Metrópoles" identificou-se o lucro líquido das construtoras, além da quantidade de áreas úteis comercializáveis de sua propriedade. Detectou-se as consequências gerais desse programa, além de analisar a segregação em seus níveis econômicos, políticos-institucionais e ideológicos.

Identificou-se, os pontos positivos e negativos, em relação às moradias construídas através do programa, como também quais são as prioridades do Estado na escolha da aplicação dos investimentos. Cumpre lembrar que não é objeto desse artigo avaliar o Programa Minha Casa Minha Vida, mas analisar as pesquisas científicas já realizadas, como também a doutrina especializada no tema, para que possamos compreender melhor as consequências que o programa trouxe em relação ao déficit habitacional e entender sua relação com as construtoras, Caixa Econômica Federal e Municípios, além de detectar a qualidade nas produções das moradias.

Por fim, também através das pesquisas publicadas no "Observatório das Metrópoles", onde foram avaliadas moradias construídas pelo programa em Estados e Municípios do Brasil, trazendo quais são os entraves ao Programa MCMV.

Para tanto, se realizou um procedimento de revisão da literatura, estrangeira e brasileira, com a sistematização e análises de dados, buscando identificar os institutos, tendo como principais fontes de pesquisa os sites do governo federal, livros, periódicos. 


\section{O ESTADO COMO PARTÍCIPE DO PROCESSO DE PRODUÇÃO DE MORADIAS E A BARREIRA À PROVISÃO DE MORADIAS DECORRENTE DA LEGISLAÇÃO URBANÍSTICA}

Sabe-se que o direito surgiu na idade contemporânea com o capitalismo, após a Revolução Industrial, estando vinculado a um modo de organização da subjetividade que permite a circulação de mercadorias. Já a superestrutura jurídica compreende as normas e as relações sociais e depende de uma organização estatal para existir, pois necessita da existência de uma autoridade que formule as normas, tendo as relações de propriedade como seu comando mais profundo.

Segundo Negri uma consideração marxista sobre o direito não pode ser simplesmente colocada nem do ponto de vista da história da economia nem do ponto de vista da crítica materialista do direito; na linguagem contemporânea, dir-se-á que é precisamente no ponto de encontro entre historicidade da experiência jurídica e de determinação dos mecanismos de domínio capitalista, entre histórica da exploração e regime das relações de produção, que é permitida uma análise mais aprofundada sobre a especificidade do direito e de seu movimento. (PACHUKANIS, 2017, p. 30-31)

Pachukanis tinha certeza de que o direito era uma forma da sociedade do capital, para ele, a propriedade vem antes da mercadoria e o direito é um ordenamento que só a burguesia e o capitalismo possuem e aplicam na sociedade. Assim, a norma é um fato objetivo que determina suas funções como relação social no interior de uma história definida pela troca mercantil:

O direito regula as relações sociais. Ao excluir dessa formulação certo antropomorfismo que the é inerente, encontra-se a seguinte proposição: a regulamentação das relações sociais em determinadas condições assume um caráter jurídico. Essa formulação, não se pode negar, é a mais correta e, historicamente, a mais justa.

Nos limitaremos a notar, por enquanto, que a regulamentação das relações sociais, em maior ou menor medida, assume um caráter jurídico, ou seja, em maior ou menor medida, pinta-se com as mesas cores que fundamentam e especificam a relação jurídica. (2017, p. 92-93)

Esse sujeito de direito é o núcleo da forma jurídica, não advém do Estado, mas das relações de produção capitalista e nasce na esfera da circulação das mercadorias. Com o sujeito de direito, "livre e igual", permite-se a negociação da propriedade privada, tornando possível a circulação de todas as mercadorias, especialmente a moradia e, são as normas estatais que permitem, esses sujeitos de direito, fazer contratos e negociar a moradia. 
Na realidade, uma clara hierarquia subordina os direitos políticos do cidadão etéreo aos interesses concretos do homem burguês apresentados como direitos naturais. Igualdade e liberdade são ficções ideológicas que pertencem ao Estado, embora a realidade que sustentam seja uma de uma sociedade e existência diária de exploração, opressão e individualismo. Assim, explica Douzinas que que os direitos do homem, como todos os direitos, não são naturais ou inalienáveis, mas criações históricas do Estado e da lei:

Os direitos civis e políticos têm uma clara prioridade sobre os sociais e econômicos. Historicamente, eles foram os primeiros a entrar na cena mundial e são superiores em virtude de seu caráter negativo e individualista. Seu objetivo é estabelecer limites em torno das atividades do Estado, abrindo, assim, áreas livres de interferência política e legal, onde indivíduos podem exercer suas iniciativas sem proibições ou controle excessivo. Para antigos liberais, essa concepção de liberdade negativa, liberdade como falta de limite ou imposição do Estado, é o coração da autonomia humana e dos direitos. Direitos econômicos, por sua vez, não são direitos legais próprios. Eles são reivindicados por grupos, não por indivíduos; são "positivos" em sua ação. Finalmente, os direitos sociais e econômicos não são "justificáveis": não podem ser garantidos pela legislação em um Estado liberal e, além do mais, os tribunais são podem fazer com que sejam cumpridos. (2009, p. 177-178)

Pachukanis afirma que ao mesmo tempo que um produto do trabalho adquire propriedade de mercadoria e se torna o portador de um valor, o homem adquire um valor de sujeito de direito e se torna portador de direitos:

Sujeito de direito é o ente cuja vontade é decisiva. O vínculo social da produção apresenta-se, simultaneamente, sob duas formas absurdas: como valor de mercadoria e como capacidade do homem de ser sujeito de direito. O homem como sujeito de direito, ou seja, como proprietário, representa também ele essa mesma condição. Por fim, ambas as determinações estão intimamente ligadas a uma terceira pessoa, na qual o homem figura na qualidade de sujeito econômico egoísta. (2017, p. 120-154)

Segundo Daniel Bensaid, Marx, em vez de considerar que a propriedade é uma categoria jurídica ilegítima, ele analisa como uma forma de intercâmbio que correspondia a um determinado estágio de desenvolvimento faz forças produtivas:

Desse modo, ele acaba secularizando e relativizando uma noção de justiça cuja definição varia historicamente. Como consequência, não há muito sentido em declarar a exploração injusta, ou em denunciar a propriedade como um furto, sem, mas precisões. São, na realidade, duas concepções do direito que se confrontam, direito contra direito, o dos possuidores contra o dos possuídos. Entre um e outro, quem decide é a força. (2017, p. 48)

Por tudo isso, percebe-se que é entre história da exploração e regime das relações de produção que se permite uma análise profunda do direito, sendo que, esse direito, regula as 
relações sociais. A forma que confere especificidade ao direito é a subjetividade jurídica, expressa na forma mercadoria e confere ao homem o título de sujeito de direito, podendo dispor de forma "livre e igual" de sua propriedade privada, através do contrato. Entretanto, essa capacidade, é uma qualidade apenas formal para praticar os atos da vida civil. Assim, a afirmação jurídica que todos são livres e iguais é uma dominação técnica e ideológica, primeiro por excluir os privilégios de alguns e, segundo, com a igualdade formal, mas não concreta, onde esconde as relações sociais de dominação.

O direito à cidade engloba o direito à moradia ${ }^{2}$ e, este, é o mais importante efeito jurídico, de fundamento social, do princípio da função social da propriedade urbana. ${ }^{3}$ Como vimos antes, atualmente, a população urbana ultrapassou a rural, ocasionando diversos problemas em razão do grande número de pessoas, dentre eles, a falta de moradia. Sabe-se que esse problema não é só dos juristas, mas também, dos arquitetos urbanistas, geógrafos, filósofos e sociólogos.

Sabe-se que o direito à moradia é um direito humano, além de ser um direito fundamental social, de segunda geração ou dimensão. Esse direito foi inserido no nosso ordenamento através da Emenda Constitucional 26 que alterou o rol dos direitos sociais do art. 6o da Constituição Federal. Além desse artigo a moradia encontra-se nos artigos 23, IX, 7으, IV, 5ำ, XXIII, 170, III e 182, § 2ํ, além dos 183 e 191, todos da Constituição Federal. ${ }^{4}$

O Estado é ator no processo de produção do espaço urbano e, esse espaço urbano é contraditório, uma vez que é produto social, mercadoria, que se refere a uma forma social específica; entretanto, por representar um valor de uso, reduz o cidadão à condição de usuário

\footnotetext{
${ }^{2}$ Existe uma diferença entre moradia, habitação, domicílio e residência. A moradia está ligada a pessoa e independe de objeto físico para existir e ser protegido; a habitação é a efetivação da moradia sobre um imóvel, ou seja, a ligação do sujeito ao bem, temporariamente; o domićlio é o lugar de habitação do indivíduo, com o ânimo de residir, em outras palavras, onde a pessoa reside com ânimo definitivo; já a residência é o local onde se encontra a pessoa. O Código Civil coloca como sinônimo o domicílio e habitação.

${ }^{3}$ Conceituou-se a função social, "como um princípio onde a propriedade deve ser dinâmica e operacionalizada, devendo extrair dela benefícios individuais, que busquem os interesses particulares, mas, principalmente, os sociais onde defende-se os fins coletivos". (ANDRADE, Diogo de Calasans Melo. 0 Princípio da Função Social da Propriedade. São Paulo: Letras Jurídicas, 2014, p. 123)

${ }^{4} \mathrm{O}$ Direito à Moradia também está presente nos documentos internacionais, são eles a pioneira Declaração Universal dos Direitos Humanos de 1948 (Artigo XXV, item 1), o Pacto Internacional de Direitos Econômicos, Sociais e Culturais, de 1966 (Artigo 11), a Convenção internacional sobre a eliminação de todas as formas de Discriminação Racial, de 1965 (Artigo V), a Convenção sobre a eliminação de todas as formas de Discriminação contra a Mulher, de 1979 (Artigo 14.2, item h), a Convenção sobre os Direitos da Criança (Artigo 21, item 1), a Declaração sobre Assentamentos Humanos de Vancouver, de 1976 (Seção III, 8 e Capítulo II, Aa.3), a Agenda 21 sobre Meio Ambiente e Desenvolvimento, de 1992 (Capítulo 7, item 6) e a Agenda Habitat, de 1996.
} 
do serviço e é, nesse espaço, que se reproduzem as relações dominantes de produção. Assim, o espaço é visível e representa relações sociais reais, reflete a ideologia prevalente dos grupos e instituições dominantes na sociedade e é moldado pela dinâmica das forças de mercado.

Segundo Marx, o Estado não pode ir contra a natureza das coisas, ele não pode blindar o finito contra as condições do finito, não pode blindá-lo contra a contingência. No entanto, o Estado assegurará o interesse privado:

Dos senhores na medida em que este puder ser garantido por meio de leis racionais e medidas preventivas racionais, mas o Estado não poderá conceder as suas demandas privadas em relação ao criminoso nenhum outro direito além do direito das demandas privadas, isto é, a proteção da jurisprudência civil. (2017, p. 120)

Por isso, sendo o Estado partícipe desse processo de produção do espaço urbano, afeta as formas legais de urbanização através das leis urbanísticas que restringem a possibilidade de ocupação democrática da propriedade privada:

As leis urbanísticas tradicionalmente no Brasil restringiram qualquer possibilidade de ocupação democrática nessas áreas, com leis de ocupação e uso do solo que conformavam a obrigatoriedade de certo padrão econômico: zonas exclusivamente residenciais com áreas mínimas de lote gigantescas, exigência de recuos significativos obrigando o aumento do lote a construir, e assim por diante. Em seguida, por uma certa liberalidade permitindo modelos de ocupação que renegam a qualidade urbana e a valorização do espaço público: condomínios fechados e fortificados, baseados em padrões de uso impactantes (como por exemplo o alto consumo de água devido à tipologia de múltiplas suítes por unidade), segmentação da malha urbana por muros e recortes, eliminação do comércio de proximidade, substituição do espaço público, das praças e passeios, por espaços privativos aos condomínios, impermeabilização do solo, e assim por diante. Some-se a isso a opção, de política "pública", por um modelo de mobilidade baseado quase que exclusivamente no automóvel individual. (FERREIRA, 2017, p. 29)

Assim, uma barreira à provisão de moradias está na legislação urbanística excessivamente detalhista e na legislação ambiental, que tornam lentos os processos de aprovação dos projetos, característica reforçada pela fragmentação presente na gestão urbana e pelas características cartoriais do patrimonialismo brasileiro:

Não são apenas as leis de uso e ocupação do solo ou os planos urbanísticos que não são observados nos bairros ilegais. Nenhuma legislação aí é aplicada e a resolução de conflitos obedece à "lei" do mais forte. A presença do Estado pode se restringir à troca de favores pontuais com finalidade eleitoral. De um modo geral, o Estado está ausente e esse vazio é ocupado por um poder paralelo. (MARICATO, 2009, p. 41-43)

Como vimos, o direito à moradia decorre do princípio da função social da propriedade e está presente tanto na Constituição Federal quanto nos planos diretores, assim, a função social da propriedade e a bandeira do direito à cidade como política pública se fez: 
Acompanhar pelas remoções de favelas com 0 consequente deslocamento dos moradores que ficaram no caminho do processo de valorização promovido pela urbanização contemporânea. Faz-se também a acompanhar pelo recrudescimento dos conflitos (com, por exemplo, a construção de coletivos, o poder mobilizador dos movimentos de moradia), pontuando formas renovadas de resistência contra a ação do mercado imobiliário e de uma justiça que se faz priorizando interesses de classes. (CARLOS, 2017, p. 49-51)

O debate em torno da importância do papel da função social da propriedade compõe um campo cego na análise, estreitando o horizonte da mudança social:

A possível centralidade da luta de moradia no conjunto das lutas aponta diretamente para o papel da propriedade privada da terra urbana e das relações contratuais que ela dissemina na sociedade, iluminando estratégias da acumulação através de articulação entre público e privado; essa situação aponta caminho radicalmente inverso dos discursos sobre a cidade, mostrando que a desigualdade se reproduz, aprofundando-se, pois, as políticas públicas realizam estratégias de classe. (CARLOS, 2017, p. 51)

Por isso, esse discurso da função social da propriedade encobre: a) o processo que tornou a propriedade uma potência estranha - autonomizando a obra social da existência humana; b) o fetiche que transforma os homens em coisas através da expropriação consentida; c) a condição da força de trabalho tornada mercadoria e sua posição de consumidora de bens e serviços; d) a função ideológica da propriedade como mecanismo que mantém o mundo tal qual é, portanto, invertido: o mundo no qual as coisas dominam os homens. (CARLOS, 2017, p. 51)

\section{O estatuto da cidade e o plano diretor como caminhos para concretizar a função social da propriedade urbana e a falta de regulamentação}

Para disciplinar as diretrizes da política urbana brasileira, ou seja, o conteúdo da função social da propriedade urbana, foi criado o Estatuto da Cidade para disciplinar os caminhos para concretização da política urbana, obrigando os municípios a incluí-los em seus planos diretores. Sobre a importância desse estatuto:

O Estado da Cidade é, sem dúvida nenhuma, uma lei moderna que modifica a estrutura jurídica, administrativa e social do Brasil. Sua fundamentação é a função social da propriedade, servindo como meio de retificação da exclusão social e demais problemas urbanos. Ele regulamentou os Artigos 182 e 183 da Constituição Federal, definindo as diretrizes gerais da política urbana. Sua denominação foi dada pela própria lei, mas merece uma crítica uma vez que se trata, apenas, de uma norma geral de direito urbanístico e não um estatuto que disciplina de 
forma detalhada e específica a gestão da cidade. (ANDRADE, 2014, p. 163)

Esse estatuto traz como instrumentos da política urbana o parcelamento e a edificação compulsória que deverão ser determinados por lei municipal específica para uma área prevista no plano diretor, devendo o Município noticiar o proprietário para cumpri-lo. Descumpridos o parcelamento ou utilização compulsória, surge o IPTU progressivo ou urbanístico, que também é um instrumento de política urbana.

Alguns motivos que dificultam a aplicação dos instrumentos urbanísticos advêm da própria legislação, ou seja, uma verdadeira via crúcis legislativa precisa ser percorrida para que haja possibilidade de aplicação desses instrumentos:

A começar pelo fato de que a lei federal que regulamentou o capítulo constitucional da política urbana - o Estatuto da Cidade - só foi aprovada treze anos após a Constituição, o que fez com que esses instrumentos adormecessem por toda a década de 1990. Após a regulamentação federal, os municípios deveriam incluí-los em seus planos diretores apontando as áreas passíveis de aplicação, o que levou mais alguns anos para ocorrer. Além disso, por determinação da própria Constituição, é preciso uma lei municipal específica baseada no plano diretor para tratar desses mecanismos de forma mais detalhada. Por fim, a administração municipal deve definir competências internas e procedimentos para viabilizar a operacionalização do PEUC, o que, em geral, demanda que seja elaborado um decreto municipal. (FROTA, 2015, p. 1)

Defendemos, que o Estatuto da Cidade determina que o proprietário deve ser notificado pelo Poder Público em razão de possuir imóvel considerado como não utilizado, subutilizado ou não edificado, localizado em área delimitada pelo Plano Diretor e, não havendo o cumprimento da obrigação pelo proprietário, será realizado, sucessivamente, a aplicação do IPTU progressivo e se, mesmo assim, o dono do bem não der adequado aproveitamento a sua propriedade, mesmo sendo cobrado 5 anos de IPTU progressivo, será imposta a desapropriação com indenização paga por meio de título da dívida pública. (ANDRADE, 2014, p. 165)

Assim, se, aplicado o IPTU progressivo e, mesmo assim, o proprietário não cumprir a função social o Poder Público Municipal poderá desapropriar o imóvel. Nesse sentido, o Estatuto da Cidade é um importante instrumento a ser utilizado pelo Munícipio para concretizar o direito à moradia com a possibilidade de desapropriar os imóveis urbanos que violam a função social da propriedade urbana:

Assim, o Estatuto da Cidade surgiu como lei federal regulamentadora dos Artigos 182 e 183 da Constituição Federal, que tem como objetivo a efetivação da política urbana para os Municípios alcançarem a função social da propriedade urbana, e, para isso, deve utilizar-se do parcelamento, edificação ou utilização compulsória do solo, do IPTU 
progressivo e da desapropriação para que se atinja a função social da propriedade urbana. (ANDRADE, 2014, p. 169)

Entretanto, como resultado de uma pesquisa ${ }^{5}$ realizada em 2014, percebeu-se que o parcelamento, a edificação ou a utilização compulsória (PEUC) é amplamente citado nos planos diretores municipais, mas pouquíssimo aplicados. Em todo o país, foram detectadas experiências de aplicação apenas em Diadema, Santo André, São Bernardo do Campo, Curitiba, Goiânia, Palmas, Maringá e São Paulo. E, em alguns desses casos, a quantidade de imóveis notificados foi insignificante e/ou não houve continuidade na aplicação. Em relação ao IPTU progressivo no tempo, é ainda menor o grupo de municípios que possuem experiências de aplicação. Até o momento, somente Maringá e São Bernardo do Campo e, a partir do próximo ano, São Paulo. (FROTA, 2015, p. 2)

Por conta disso, o Estatuto da Cidade disciplina o conteúdo da função social da propriedade urbana, definindo as diretrizes da política urbana que, se não forem atendidas pelo proprietário, o Poder Público Municipal poderá se valer dos seguintes instrumentos da política urbana: parcelamento e edificação compulsória, IPTU progressivo e desapropriação. Acontece que, esses importantes instrumentos jurídicos não são aplicados de fato, uma vez que dos 5570 municípios que temos, somente 8 regulamentaram essa lei.

Por outro lado, o plano diretor ${ }^{6}$ é o instrumento básico de política de desenvolvimento e expansão urbana e de competência do Poder Legislativo Municipal e, segundo o Estatuto da Cidade, a propriedade urbana cumpre a sua função social quando atendidas as exigências do Plano Diretor. Assim, achou por bem o legislador eleger o plano diretor como instrumento para fixar os requisitos da função social da propriedade urbana para cada Município.

Por isso, quem define a função social da propriedade urbana, segundo a Constituição Federal e o Estatuto da Cidade, é o plano diretor de cada cidade que, de acordo com a política urbana, estabelece os requisitos para atender a função social dos seus imóveis urbanos, ou seja, a função social da propriedade urbana é atendida quando se observa o Plano Diretor. Assim, se determinada propriedade não tiver atendendo sua função social seu proprietário pode sofrer as penas acima descritas e previstas na Lei Maior, regulamentadas pelo Estatuto da Cidade.

\footnotetext{
${ }^{5} \mathrm{~A}$ pesquisa foi realizada em 2014 por uma equipe da Universidade Federal do ABC, coordenada pela Profa. Rosana Denaldi, no âmbito do Programa Pensando o Direito, da Secretaria de Assuntos Legislativos do Ministério da Justiça, e contou também com apoio do Ministério das Cidades.

${ }^{6} \mathrm{O}$ Plano Diretor é uma lei municipal, instrumento de política de desenvolvimento e expansão urbana, obrigatório para as cidades com mais de 20 mil habitantes e tem como finalidade o desenvolvimento das funções sociais da cidade e o bem-estar dos cidadãos, sujeitando o prefeito que não apresentar o projeto na Câmara Municipal a responder por improbidade administrativa, (ANDRADE, Diogo de Calasans Melo. 0 princípio da função social da propriedade. São Paulo: Letras Jurídicas, 2014, p.179)
} 
De mais a mais, os municípios, em sua grande maioria, elaboraram seus planos diretores e, em grande número desses planos, o tema moradia, solo urbano e instrumentos de política fundiária estão presentes, entretanto, as limitações e fragilidades desses processos de planejamento locais:

Em primeiro lugar, estes foram elaborados em sua grande maioria sem referências ou marcos de planejamento regionais e, muito menos ainda, nacionais. Essa questão é particularmente importante e problemática no caso das regiões metropolitanas ou na relação do planejamento local com as bacias hidrográficas que transcendem as fronteiras municipais. Esse é um limite da ação exclusivamente focada no município utilizada na Campanha pelos Planos Diretores Participativos, fruto mais das contingências do momento - prazo de 2006 definido pelo Estatuto da Cidade e a necessidade de que este não se transformasse imediatamente em "lei que não pega" antes mesmo de ser experimentado - do que propriamente de uma opção radicalmente descentralizadora. (ROLNIK, 2011, p. 154-155)

Esse plano diretor tornou-se um instrumento desgastado em virtude das possibilidades que vinha apresentando de ser manipulado e desvirtuado pelos setores reacionários que dominam a produção do espaço urbano; consequentemente, a elaboração de vários planos diretores para importantes cidades do país no início dos anos de 1990 não conseguiu mobilizar os movimentos populares urbanos. (VILLAÇA, 2015, p. 238)

Outro entrave em relação ao plano diretor é a falta de obrigatoriedade de vincular os ciclos orçamentários subsequentes à aprovação de planos diretores às suas definições e propostas:

Na área de desenvolvimento urbano, pouca autonomia real tem as arenas decisórias locais sobre estes investimentos - sejam elas participativas ou não -, uma vez que a área de desenvolvimento urbano do Estado brasileiro permanece estruturada em burocracias altamente setorializadas e centralizadas que funcionam através de processos decisórios bastante penetrados pelos interesses de atores econômicos e políticos que deles dependem para sobreviver. Este fato nos ajuda a entender algumas características da política urbana que bloqueiam as tentativas de implementação de uma agenda de reforma na direção de cidades pactuadas e planejadas democraticamente em uma esfera pública. Uma complexa rede de corretagem política que vai dos altos escalões aos espaços locais intermedeia a transferência de recursos para os municípios, tanto através das emendas como dos convênios e acesso ao crédito. (ROLNIK, 2009, p. 47)

Acontece que, poucos são os municípios ${ }^{7}$ que regulamentam a função social da propriedade, como o Município de São Paulo, que em 2014, através de decreto, regulamentou:

${ }^{7}$ Em relação ao Município de Aracaju podemos perceber que apesar de ter sido mantido os requisitos da função social no novo Plano Diretor do Município de Aracaju, a demora na aprovação da Lei 
O decreto estabelece os procedimentos e prazos de todas as etapas de um processo que inicia com a notificação e que pode resultar, no sétimo ano, em desapropriação do imóvel pelo valor venal, com pagamento em títulos da dívida pública (em vez de dinheiro).

Esse decreto regulamenta o que já está definido na Constituição, no Estatuto da Cidade, no Plano Diretor e em lei municipal de 2010. Não é qualquer imóvel vazio ou subutilizado que está sujeito a sanções, apenas aqueles que não cumprem com a missão estabelecida no Plano Diretor. (ROLNIK, 2014, p. 1)

Não custa lembrar que a elite brasileira se cercou de uma imensa teia de organismos e burocracia (além da ajuda do Judiciário) para impedir que a maior parte da população, especialmente os trabalhadores pobres, tivesse acesso à propriedade fundiária. O latifúndio permanece intocável durante todo o período de modernização e industrialização do país, apesar das polêmicas alimentadas pela proposta liberal de substituição dos escravos pela colonização branca durante o século XIX. (MARICATO, 2009, p. 44)

Por isso, o plano diretor, importante instrumento de política de desenvolvimento e expansão urbana, que estabelece os requisitos da função social da propriedade urbana com a finalidade da concretização do direito à moradia, são elaborados sem referência ou marcos de planejamento e não são devidamente atualizados e regulamentados, o que compromete a aplicação do princípio constitucional da função social da propriedade urbana e, consequentemente, o direito à moradia.

\section{A política nacional de habitação ( $P N H)$ e o plano nacional de habitação (PlanHab): estratégias não adotadas pelo PMCMV}

Por outro lado, com a criação do Ministério das Cidades, em 2003, o desenho definido para a Política Nacional de Habitação (PNH) apontava claramente para dois eixos de atuação: um voltado para provisão de novas unidades e outro para a urbanização de assentamentos precários, consolidando, em nível legal, a pauta da Reforma Urbana. Em vários municípios do Brasil, esse movimento, que tinha como origem o debate constituinte (1986-1988), tinha gerado práticas das administrações locais, voltada para a urbanização e regularização das

Complementar, ocasiona um grande prejuízo para a cidade, uma vez que a norma em vigor, que possui mais de 13 anos, está em desconformidade com a atual realidade social, sendo necessária a aprovação definitiva do Plano Diretor de 2010 para que criem-se novas diretrizes para a função social da propriedade urbana. (ANDRADE, Diogo de Calasans Melo. O princípio da função social da propriedade. São Paulo: Letras Jurídicas, 2014, p.182) 
favelas, sendo os eventuais reassentamentos necessários tratados dentro de uma lógica que privilegiava o direito à moradia. (CARDOSO, 2017, p. 225)

Seguindo a proposta do Projeto Moradia, a Política Nacional de Habitação (PNH) tomou como ponto de partida que a moradia na cidade adquire sentido apenas no contexto da política urbana. Ainda de acordo com o Projeto Moradia, a PNH depende fundamentalmente de três eixos: política fundiária, política financeira e estrutura institucional. Os aspectos relacionados à construção civil estariam dependentes dessa matriz formada por fatores determinantes. (MARICATO, 2006, p. 216)

Segundo a tese que sustenta a PNH, é preciso combinar ações que ampliem o mercado privado em direção às classes médias:

que atualmente não encontram alternativas para sua moradia e ações de promoção pública que deem conta da população de rendas mais baixas, especialmente aquelas situadas no intervalo de 0 a 5 salários mínimos. Dessa forma espera-se evitar que as classes médias se apropriem dos recursos públicos (ou semipúblicos como o FGTS), como aconteceu durante os anos que precederam o governo Lula, conforme mostra o gráfico abaixo. (MARICATO, 2006, p. 217)

Um dos componentes centrais da nova Política Nacional de Habitação (PNH), objetiva planejar as ações públicas e privadas, em médio e longo prazo, para equacionar as necessidades habitacionais do país no prazo de quinze anos:

Foi concebido como um plano estratégico de longo prazo coordenado com propostas a serem implementadas a curto e médio prazo, tendo como horizonte 2023. Suas propostas e etapas se articulam com a elaboração dos PPAs, prevendo-se monitoramento, avaliações e revisões a cada quatro anos $(2011,2015,2019)$. A estratégia exige ações simultâneas em quatro eixos indispensáveis: financiamentos e subsídios; arranjos institucionais; cadeia produtiva da construção civil; estratégias urbano fundiárias. Esses eixos estão intrinsecamente articulados. Não haverá alterações substanciais no quadro da política habitacional se não forem realizadas ações concomitantes nas quatro frentes. A ampliação dos recursos para habitação é central no PlanHab, de modo a criar uma nova política de subsídio baseada em grupos de atendimento por capacidade de retorno ao financiamento, em que os mais pobres são beneficiados e os que têm alguma capacidade de pagar, mas representam risco para os agentes financeiros, podem utilizar um Fundo Garantidor. (BONDUKI, 2009, p. 12)

Essa PNH, instituído em 2004, conta com a ação conjunta do Sistema Nacional de Habitação, o Desenvolvimento Institucional, o Sistema de Informação e Avaliação e Monitoramento da Habitação, além do Plano Nacional de Habitação (PlanHab). Esse PNH atua de duas formas, uma voltada à provisão de novas moradias e outra urbanizando os assentamentos precários. Assim, seus eixos são a política fundiária, política financeira e 
estrutura institucional. Por fim, seu objetivo era planejar as ações públicas e privadas, durante 15 anos, para combater o déficit habitacional.

O objetivo da PlanHab é a mobilização de recursos, através de uma ação conjunta da União, Estados, Distrito Federal e Municípios, para reduzir o déficit habitacional. Nesse viés, surge esse plano, através de ações públicas e privadas, onde busca equacionar as necessidades habitacionais no Brasil, tendo como base quatro eixos: o financiamento, arranjos institucionais, cadeia produtiva da construção civil e estratégias urbano fundiárias.

A política habitacional teve efeito perverso, concebida para atenuar desigualdades sociais, termina ela por acentuá-la mais ainda, concorrendo para agravar a concentração da renda no país:

Vista em seus próprios termos, faltou à política habitacional imaginação - ou decisão política - para encontrar a solução que melhor se amoldasse às condições das classes baixas. Desconheceram-se os mecanismos espontâneos de que lançam mão tais classes para atender suas necessidades habitacionais.

Em consequência, limitou-se a política à ação "tapa-buraco", construindo aqui e ali conjunto populares, arranhando mais que enfrentando o problema.

A falência da política de habitações populares pode ser melhor aquilatada pela expansão do chamado mercado informal, paralelo ou clandestino, formado pelas moradias construídas sem licença das prefeituras, pelas populações de baixa renda. Indício de fraco desempenho do banco é também o crescimento acelerado dos domicílios rústicos nos últimos anos. (AZEVEDO, 2011, p. 108)

Assim, em dezembro de 2009, foi publicado o Plano Nacional de Habitação ${ }^{8}$ (PlanHab) com o intuito de apresentar instrumentos capazes de enfrentar as necessidades habitacionais, presentes e futuras, propondo-se que é possível transformar as condições de moradia do país, com a participação ativa dos setores públicos e privados, dos agentes e dos movimentos sociais. Para o plano, o lançamento do Programa Minha Casa Minha Vida (PMCMV), em 2009, colocou em curso um conjunto de diretrizes previstas no PlanHab.

Esse PlanHab propôs incentivar, com prioridade no acesso aos recursos, os municípios que adotassem políticas fundiárias e urbanas corretas, como a instituição do imposto

\footnotetext{
8“Plano Nacional de Habitação - PlanHab é um dos mais importantes instrumentos para a implementação da nova Política Nacional de Habitação. Previsto na Lei 11.124/05, que estruturou o Sistema Nacional de Habitação de Interesse Social, ele foi elaborado, sob a coordenação da Secretaria Nacional de Habitação do Ministério das Cidades, pela consultoria do Consórcio PlanHab, formado pelo Instituto Via Pública, Fupam-LabHab-FAUUSP e Logos Engenharia, por meio de um intenso processo participativo, que contou com a presença de todos os segmentos sociais relacionados com o setor habitacional". (Plano Nacional de Habitação. Versão para debates Brasília: Ministério das Cidades/Secretaria Nacional de Habitação Primeira impressão: Maio de 2010)
} 
progressivo para combater os imóveis ociosos e subutilizados, lembrando que quase 2 mil municípios formularam planos diretores e, na sua grande maioria, não puseram em prática instrumentos para combater a especulação imobiliária. (BONDUKI, 2009, p. 13-14)

O PlanHab pretende introduzir o planejamento habitacional em nível federal, contribuindo para firmar o acesso à moradia como política social e de Estado:

Esta não é uma tarefa fácil. Não há no setor habitacional tradição de planejamento, nem se detém de informações sistematizadas para todo o país sobre vários aspectos do problema de que estamos tratando. Mesmo com algumas restrições de dados o Estado Brasileiro busca montar uma estratégia planejada, que leva em conta a diversidade das necessidades, os custos variados de produção da moradia e o contexto dos Municípios brasileiros. (BONDUKI, 2008, p. 35)

Assim, o PNH, através de uma ação conjunta público e privado, busca diminuir o déficit habitacional, no prazo de 15 anos, para isso, utiliza-se de seu mais importante instrumento que é o PlanHab, que tem como objeto implementar a PNH. O PlanHab divide-se em 3 etapas, a 1a (2009-2011) transição e implementação, a 2ạ (2012-2015) consolidação e a 3ạ (2016-2023) conquista e resultados. Sobre a terceira fase:

Para esse período futuro, a expectativa é de que o programa de urbanização de assentamentos precários tenha apresentado resultados favoráveis, podendo, nesta 3a etapa, receber uma prioridade menor, para que os esforços possam ser fortemente concentrados na produção de unidades novas. ${ }^{9}$

Para Bonduki, o PlanHab previu um leque de alternativas habitacionais a custos unitários mais reduzidos (como lotes urbanizados e/ou material de construção com assistência técnica), com potencial de atender um número maior de famílias; já o Minha Casa, Minha Vida fixou-se na produção de unidades prontas, mais ao gosto do setor da construção civil. O programa não adota o conjunto das estratégias que o PlanHab julgou indispensável para equacionar o problema habitacional, sobretudo nos eixos que não se relacionavam com os aspectos financeiros; em consequência, aborda-o de maneira incompleta, incorrendo em grandes riscos, ainda mais porque precisa gerar obras rapidamente sem que se tenha preparado para isso. (BONDUKI, 2008, p. 13-14)

No mesmo sentido, considerando o desenho institucional adotado para o programa fortemente ancorado no protagonismo do setor privado -, o PMCMV entrou em choque com os princípios do SNHIS pautados no papel estratégico do setor público, ignorando em larga medida as premissas e os debates acumulados em torno do Plano Nacional de Habitação de Interesse

\footnotetext{
${ }^{9}$ Plano Nacional de Habitação. Versão para debates Brasília: Ministério das Cidades/ Secretaria Nacional de Habitação Primeira impressão: Maio de 2010
} 
Social (PlanHab) que vinha sendo amplamente discutido desde 2007. Um dos impactos mais imediatos sobre os programas desenvolvidos no âmbito do FNHIS diz respeito à eliminação dos repasses de recursos para as ações de provisão habitacional. (CARDOSO, 2017, p. 29)

É fato e deve-se afirmar aqui de maneira bastante direta, que o MCMV injetou recursos bastante significativos na produção habitacional e que estabeleceu mecanismos de subsídio diretos e explícitos, como propunha a Política Nacional de Habitação e o PlanHab; e, assim, por meio dessa equação financeira, ampliou o atendimento para faixas de renda antes atendidas de forma restrita. (KRAUSE, 2013, p. 45)

Entretanto, tomando então o PlanHab como referência, pode-se ver que o MCMV se afasta ainda mais daquilo que preconizava a política habitacional, o conhecimento de diferentes realidades para o melhor enfrentamento do déficit habitacional:

Em um país de dimensões continentais, com profundas desigualdades regionais, sociais, econômicas e uma enorme diversidade cultural, o MCMV se expressa como uma empresa fordista na produção em grande escala, cuja imagem predominante, ainda que não a única, são "casinhas" a perder de vista. Forma única, isto sim, de execução, padronização dos produtos, interesses e arranjos das empresas racionalizando a proposição de empreendimentos, a desconsideração de uma tipologia das cidades que receberiam os investimentos e a mais intensa ligação com as necessidades habitacionais, são alguns dos elementos identificados e explorados no texto. (KRAUSE, 2013, p. 47)

Por outro lado, a falta de capacidade das prefeituras, Estados e do próprio agente financeiro (Caixa) para uma atuação em larga escala, os constrangimentos da cadeia produtiva, cujos produtos, em geral, não estão adequados para atender à demanda prioritária, a dificuldade de acesso e o custo da terra urbanizada e regularizada para a produção da Habitação de Interesse Social (HIS), em condições urbanas e ambientais adequadas, são obstáculos para a aplicação dos recursos, com foco na população prioritária. Por isso, o PlanHab propõe ações simultâneas nos quatro eixos. (BONDUKI, 2009, p, 12)

Por sua vez, o MCMV tem fraca aderência às estratégias de enfrentamento do déficit habitacional, o que o distancia num primeiro momento de uma política habitacional stricto sensu, especialmente de habitação de interesse social:

Seguindo esta lógica destacamos que há uma maior correlação das contratações do MCMV, para faixas de maior renda, com a demanda por habitação conforme calculada pela CAIXA, ou seja, com a expectativa de inserção das famílias no mercado por meio da compra de um imóvel. Numa perspectiva comparada, o MCMV/FGTS mostraria, portanto, melhor focalização do programa na escala municipal, em comparação com o MCMV-FAR. (KRAUSE, 2013, p.46) 
Faz-se necessário fazer uma pesquisa científica específica, que não é o objetivo deste artigo, para perceber se o Programa Minha Casa Minha Vida acompanha as diretrizes do Plano Nacional de Habitação. Entretanto, detectamos os eixos do PlanHab, quais sejam, o financiamento, arranjos institucionais, cadeia produtiva da construção civil e estratégias urbanas fundiárias, como também, seu objetivo de introduzir o planejamento habitacional em nível federal, contribuindo para firmar o acesso à moradia como política social e de Estado. No entanto, comungamos com a doutrina especialista no assunto para afirmar que o PMCMV não adota o conjunto de estratégias que o PlanHab julga necessário para diminuir o déficit habitacional no Brasil e, também, ignorou as premissas e os debates em torno do plano que vinha sendo discutido desde 2007.

Por tudo que foi exposto, percebe-se que o direito, através da superestrutura jurídica, traz normas que transformam os cidadãos em sujeitos de direito e, através da subjetividade jurídica, torna possível que exista a negociação, "livre e igual", da moradia. Acontece que o direito à moradia, considerado como direito humano e fundamental, necessita de diversos instrumentos jurídicos, tais como o Estatuto da Cidade, o Plano Diretor, a Política Nacional de Habitação e do Programa Minha Casa Minha Vida para ser aplicado. Entretanto, essa arrumação legal tem o feito contrário, trazendo diversos obstáculos, para não efetivar o direito à moradia.

\section{A "SOLUÇÃO" MARXISTA PARA ESCASSEZ DE MORADIA}

Nessa parte deste artigo trouxemos os conceitos de forma jurídica, agora aplicada, especificamente, à moradia; o estudo da intervenção estatal para preservar essa forma; as possíveis "soluções" da doutrina marxista para eliminar a escassez de moradia; a relação entre as favelas e o déficit habitacional; a análise do Programa Minha Casa Minha Vida, compreendendo suas fases, faixas, finalidade e agentes; a responsabilidade dos Municípios; a ligação entre utilização dos investimentos públicos e o lucro das construtoras e, por fim, a união entre Estado, construtoras, Caixa e Município e, suas consequências, para a questão da moradia.

Para Marx, quando se introduz materialmente em nosso direito o interesse privado, que não suporta a luz da dimensão pública, deve-se dar a ele também uma forma adequada, ou seja, um processo confidencial, para que pelo menos não sejam despertadas nem nutridas ilusões perigosas e presunçosas. A forma não tem valor, se não for a forma conteúdo. (MARX, 2017, p. 125) 
Entretanto, foi Pachukanis que relacionou a forma mercadoria com a jurídica, entendendo que a forma jurídica é reflexo da forma mercantil. Ele afirma que a forma do direito, expressa por abstrações lógicas, é produto da forma jurídica real ou concreta, uma mediação real das relações de produção; ele apontou que a gênese da forma jurídica deve ser procurada nas relações de troca e destacou o momento que representa a mais completa realização da forma jurídica, a saber, o tribunal e o processo judicial. (PACHUKANIS, 2017, p. 64)

Sabe-se que a forma mercadoria é propriedade abstrata de valor e é constituída das relações sociais, ou seja, pelas interações sociais; já a forma jurídica é reflexo da relação social (relação dos proprietários), considerada como um dado histórico social concreto e seu desenvolvimento se dá com a circulação mercantil e é, através do princípio da equivalência, que se permite sua constituição. Além disso, detectou-se, que existe um profundo vínculo jurídico interno entre a forma jurídica e a forma mercantil.

Segundo Negri, o conceito de forma do direito para Pachukanis surge quando se coloca o problema não simplesmente da base (econômica) da qual emana o poder jurídico e se desenvolve seu funcionamento sistêmico, mas também se trata de definir a potência estendida do ordenamento legal e a convergência de legitimidade e efetividade que dá a sua força:

Ora, insiste Pachukanis, a "forma" do direito se impõe na complexidade das condições sociais que ela encarna e exprime. Não se trata de simples forma técnica ou mera projeção de conteúdos normativos, mas da instituição do valor social do trabalho e dos equilíbrios/desequilíbrios que se desenvolvem nos processos de determinação institucional. A regra constitutiva da "forma" é a mesma que a desmistifica, como acontece nos textos que Marx dedica ao fetichismo, porque mostra as relações de força que a constituem. (2017, p. 51-52)

Por outro lado, a propriedade dos meios de produção e da terra atravessa a história tornando-se abstrata no capitalismo através de sua forma jurídica (a propriedade privada):

E, nesta condição, naturaliza dominando e diferenciando aos indivíduos e expandindo-se através da subordinação de todas as relações sociais à sua lógica, em diferentes formas; o desdobramento da propriedade no mundo moderno realiza-se muito além do mundo dos objetos criados no processo produtivo, dominando todas as formas de produção humana, dentre elas a cidade. Nesta perspectiva, a sociedade urbana vive a cidade como exterioridade - fonte de privação - o que atualiza os termos da alienação gerando lutas no espaço, isto é, pelo espaço da vida, na cidade. (CARLOS, 2017, p. 59)

Por outro lado, a intervenção estatal é de fato necessária para preservar a formamercadoria (assegurando as condições de funcionamento do mercado), a mesma é também antagonista com aquela última, ao impor um limite à expansão da forma-mercadoria precisamente enquanto a medida em que a sustenta. Assim, a tendência para a generalização 
da forma-mercadoria levanta uma contra tendência que a nega, a saber, a sempre mais abrangente intervenção estatal e a produção direta de valores de uso, isso é o que se chama de dialética da forma-mercadoria. (DEAK, 2016, p. 181)

No que pertine à moradia, à quantidade, à qualidade, ao status e à forma da moradia resultam da conjunção de quatro sistemas:

O sistema de produção deste bem durável que ele representa, o sistema de distribuição social deste produto, o sistema de distribuição sociais dos homens (função de seu lugar na produção e na gestão); o sistema de correspondência entre os dois sistemas de distribuição. O resultado assim obtido articula-se no sistema ideológico (utopias urbanísticas, imagens arquiteturais etc.) que o reforça e dá-lhe uma coerência, através de sua constituição em forma material e em mito residencial. A profundidade significativa da moradia pode ser desvendada desta forma, a partir da compreensão do processo social que o determina. (CASTELLS, 2014, p. 249)

Um dos primeiros marxistas que analisou a questão da moradia foi Engels, em sua obra "Sobre a questão da moradia" quando detectou que a escassez de moradia não é peculiar da época atual, não é nem mesmo um dos sofrimentos peculiares do proletariado moderno em comparação com todas as classes oprimidas anteriores; pelo contrário, ela atingiu todas as classes oprimidas de todos os tempos de modo bastante homogêneo e para pôr um fim a essa escassez de moradia só existe um meio:

eliminar totalmente a espoliação e a opressão da classe trabalhadora pela classe dominante. - O que hoje se entende por escassez de moradia, é o peculiar agravamento das más condições de moradia dos trabalhadores em razão da repentina afluência da população às metrópoles; é o aumento colossal dos preços do aluguel; é a aglomeração ainda maior de moradores nas casas particulares; e, para alguns, é a total impossibilidade de encontrar alojamento. E a única razão pela qual essa escassez de moradia passou a ser tema frequente é que ela não se limitou à classe trabalhadora, mas acabou atingindo também a pequena burguesia. (2015, p. 38)

Para Castells essa carência das moradias, as falhas de equipamento e de salubridade do espaço residencial resultam do aumento brusco da concentração urbana, num processo denominado lógica da industrialização:

Assim, a moradia é um dos elementos essenciais da reprodução da força do trabalho, como tal, ela segue os movimentos de concentração, dispersão e distribuição dos trabalhadores e também provoca, em caso de crise, um ponto de estrangulamento importante no processo de produção.

$\ldots$

Assim, quanto maior a taxa de crescimento industrial (capitalista), mais intenso é o crescimento urbano, maior é a tendência à concentração em grandes aglomerados e maior é a penúria de moradias como também a 
deterioração do patrimônio imobiliário. É necessário, contar, além disso, os mecanismos multiplicadores da crise: em situação de penúria, desenvolve-se a especulação, os preços sobem, a rigidez social faz-se maior, a dificuldade do problema amortece as iniciativas para resolvê-lo, contribuindo assim para agravá-lo e para desenvolver em espiral o círculo vicioso da crise. (2014, p. 226)

No mesmo viés, a escassez de moradia dos trabalhadores de uma parcela dos pequeno burgueses de nossas metrópoles modernas constitui uma das inumeráveis precariedades de menor importância, secundárias, que decorrem do atual modo de produção capitalista. De modo algum é consequência direta da espoliação do trabalhador, enquanto trabalhador, pelo capitalista. Essa espoliação é o mal fundamental que a revolução social quer abolir, abolindo o modo de produção capitalista. (ENGELS, 2015, p. 38)

Embora, individualmente, o capitalista lamente a escassez de moradia, dificilmente mexerá um dedo para dissimular mesmo que superficialmente suas consequências mais terríveis, e o capital global, o Estado, também não fará mais do que isso; quando muito, tomará providências para que o grau de dissimulação superficial que se tornou usual seja aplicado em toda parte do mesmo modo. (ENGELS, 2015, p. 100)

Assim, os problemas com a falta de moradia não são eliminados, mas apenas transferidos para outro lugar:

A mesma necessidade econômica que os gerou no primeiro local também os gerará no segundo. E enquanto existir o modo de produção capitalista, será loucura querer resolver isoladamente a questão da moradia ou qualquer outra questão social que afete o destino dos trabalhadores. A solução está antes na abolição do modo de produção capitalista, na apropriação de todos os meios de vida e trabalho pela própria classe trabalhadora. (ENGELS, 2015, p.108)

A burguesia resolve a questão da moradia da seguinte forma: os focos de epidemias, as covas e os buracos mais infames em que o modo de produção capitalista trancafia nossos trabalhadores noite após noite não são eliminados, mas apenas transferidos para outro lugar. A mesma necessidade econômica que os gerou no primeiro local também os gerará no segundo e, enquanto existir o modo de produção capitalista, será loucura querer revolver isoladamente a questão da moradia ou qualquer outra questão social que afete o destino dos trabalhadores, a solução está na abolição do modo de produção capitalista, na apropriação de todos os meios de vida e trabalho pela própria classe trabalhadora. (ENGELS, 2015, p. 108)

Por outro lado, é um contrassenso querer solucionar a questão da moradia e preservar as metrópoles modernas pois as metrópoles modernas, contudo, somente serão eliminadas pela abolição do modo de produção capitalista e, quando esta tiver sido posta em marcha, as 
questões que deverão ser tratadas serão de natureza bem diferente daquelas de conseguir para cada trabalhador uma casinha que the pertença. (ENGELS, 2015, p. 80)

Engels, na mesma obra (Sobre a questão da moradia), critica a ideia de Proudhon que é necessária a abolição da moradia de aluguel, mais precisamente, da forma da exigência de que cada locatário seja transformado em proprietário de sua moradia:

A moradia de aluguel será resgatada...Ao atual dono da casa será pago até o último centavo do valor de sua casa. Até agora o aluguel pago representou o tributo que o locatário paga ao direito perene do capital; em vez disso, a partir do dia em que for proclamado o resgate da moradia de aluguel, a soma paga pelo locatário, regulamentada com exatidão, será o pagamento anual da prestação da moradia da qual ele tomou posse.... Por essa via, a sociedade...se transforma numa totalidade de possuidores livres e independentes de moradias. (ENGELS, 2015, p. 50)

Assim, essa medida, que Proudhon acreditou ser revolucionária, é hoje praticada em todos os países por companhias de especuladores que, nesses termos, aumentando o preço dos aluguéis, fazem com que se pague duas a três vezes o valor das casas. (ENGELS, 2015, p. 54)

O proprietário de uma moradia, na qualidade de capitalista, tem não só o direito, mas também de certo modo, em virtude da concorrência, o dever de obter por sua casa, sem nenhum escrúpulo, os aluguéis mais altos possíveis; numa sociedade desse tipo, a escassez de moradia não é um acaso, é uma instituição necessária, que só pode ser eliminada, com repercussões sobre a saúde etc., quando a ordem social da qual ela se origina for revolucionada desde a base. (ENGELS, 2015, p. 71)

Por isso, a questão da moradia só poderá ser resolvida quando a sociedade tiver sido revolucionada a ponto de poder se dedicar à supressão da oposição entre cidade e campo, levada ao extremo pela atual sociedade capitalista:

A sociedade capitalista, longe de poder suprimir essa oposição, é forçada, ao contrário, a exacerbá-la diariamente.

....

Em suas estruturas-modelo não existe mais a oposição entre cidade e campo. Ocorre, portanto, o contrário do que afirma Sax: não é a solução da questão da moradia que leva simultaneamente à solução da questão social, mas é pela solução da questão social, isto é, pela abolição do modo de produção capitalista que se viabiliza concomitantemente a solução da questão da moradia. (ENGELS, 2015, p. 80)

Assim, para Engels a crise da moradia é uma instituição necessária que não pode ser eliminada. Comentando esse trecho desse livro "A questão da moradia", Castells afirma que a questão da moradia é primordialmente a de sua crise e, o que caracteriza esta crise é:

que ela afeta outras camadas sociais além das que se encontram embaixo da escala de rendas e atinge amplos setores dos estratos médios, que se situam melhor em outros domínios do consumo, mas não podem escapar 
da penúria das moradias, suscitadas pela concentração urbana. Esta penúria não é uma necessidade inexorável dos processos de urbanização; ela responde a uma relação entre a oferta e a procura, a qual é determinada pelas condições sociais de produção do bem, objeto do mercado, quer dizer, a moradia. (2014, p. 222)

Por isso, a crise da moradia não é puramente conjuntural e simples questão de equilíbrio entre oferta e a demanda, pois trata-se de uma defasagem necessária entre as necessidades, socialmente definidas, da habitação e a produção de moradias e de equipamentos residenciais; assim, é necessária a determinação estrutural desta defasagem, bem como suas peculiaridades históricas, pois a moradia pode ser caracterizada, por um lado, com relação a seu lugar no conjunto do sistema econômico e, por outro, enquanto produto com características específicas. (CASTELLS, 2014, p. 224-225)

Por isso, a questão da moradia só poderá ser resolvida quando a sociedade tiver sido revolucionada a ponto de poder se dedicar à supressão da oposição entre cidade e campo, levada ao extremo pela atual sociedade capitalista:

A sociedade capitalista, longe de poder suprimir essa oposição, é forçada, ao contrário, a exacerbá-la diariamente.

....

Em suas estruturas-modelo não existe mais a oposição entre cidade e campo. Ocorre, portanto, o contrário do que afirma Sax: não é a solução da questão da moradia que leva simultaneamente à solução da questão social, mas é pela solução da questão social, isto é, pela abolição do modo de produção capitalista que se viabiliza concomitantemente a solução da questão da moradia. (ENGELS, 2015, p. 80)

Pelo exposto, segundo essa corrente marxista, para pôr um fim na escassez da moradia deve-se eliminar a espoliação e a opressão da classe trabalhadora pela classe dominante, sendo a moradia um dos elementos essenciais da reprodução da força de trabalho. No entanto, essa escassez decorre do atual modo de produção capitalista e, os problemas relativos à moradia, não são resolvidos, mas, somente, transferidos de um lugar para outro. Assim, a solução é a abolição do modo de produção capitalista e a apropriação dos meios de vida e trabalho pela classe trabalhadora.

Nesse sentido, Engels critica a ideia de Proudhon que defende o resgate da moradia, com a declaração que o valor pago pelo aluguel, por parte do locatário, sirva de pagamento pelo preço do imóvel ao proprietário, transformando o locatário em proprietário. Por outro lado, argumenta que se deve acabar com o documento legal (título de propriedade), uma vez que para solucionar a questão da moradia deve-se extinguir o modo de produção capitalista, haja vista que a solução da questão social, com a abolição desse modo, soluciona, também, a questão da moradia. 


\section{O DÉFICIT HABITACIONAL E O PMCMV: A ENTREGA DAS DECISÕES DAS POLÍTICAS HABITACIONAIS PARA O SETOR PRIVADO FINANCEIRO E IMOBILIÁRIO NO BRASIL}

Em contrapartida, afirma Ferreira que cerca de $40 \%$ da população das grandes cidades vive hoje na informalidade, em favelas, loteamentos irregulares ou clandestinos, cortiços, ou mesmo nas ruas. Isso sem falar da parcela importante que vive dentro da legalidade, mas ainda assim em bairros e casas bastante precários. Entender a cidade sem enxergar tal contingente populacional, enquanto os noticiários são regularmente invadidos pelas tragédias - enchentes, deslizamentos, incêndios - que se abatem invariavelmente sobre ele tornou-se um exercício de cinismo por demais inaceitável. (FERREIRA, 2017, p. 37)

No mesmo sentido, Davis atribuiu ao Brasil a proporção de $36,6 \%$ da população urbana morando em favelas, como sua tabela é uma classificação baseada em número absolutos e, para chegar a esse número, o autor soma na conta das favelas locatários informais, cortiços, loteamentos ilegais e moradores de rua, assim, o Brasil está situado como o terceiro país do mundo com maior população moradora de favelas, atrás apenas da Índia e da China. (MIKE, 2006, p. 221)

Por isso, questão fundiária e imobiliária está na base do travamento desse mercado:

A ocupação indiscriminada de várzeas, encostas de morros, áreas de proteção de mananciais, beira de córregos enfim, áreas ambientalmente frágeis e protegidas por lei são as mais agredidas pela falta de alternativas de moradia no mercado legal, para a maior parte da população das metrópoles e cidades grandes. (MARICATO, 2002, p. 86)

Maricato afirma que os indicadores de moradias urbanas construídas a partir da invasão de terras mostram que a invasão, espontânea ou organizada, é uma alternativa habitacional que faz parte da estrutura de provisão de habitação no Brasil:

Nesse sentido, apesar de ilegal, ela é institucional: é funcional para a economia (barateamento da força de trabalho) e também para o mercado imobiliário privado, e é ainda funcional para a orientação dos investimentos públicos dirigidos pela lógica da extração concentrada e privatista da renda fundiária. (MARICATO, 2002, p. 83)

Por tudo isso, percebe-se, que em virtude do número de pessoas que moram em habitações informais, a criação das favelas se torna alternativa para a falta de habitação e, a invasão de terras, apesar de ser "ilegal" é institucional e funcional para a economia, para o mercado imobiliário e para os investimentos público, como o objetivo da extração da renda fundiária. 
Atualmente, sabe-se que cerca de 5 milhões $^{10}$ de domicílios residenciais estão vagos nos centros urbanos e o déficit ${ }^{11}$ habitacional do Brasil é de 5,8 milhões ${ }^{12}$ de moradias. Ocorre que, a dimensão da inadequação dos domicílios era mais assustadora, 10 milhões, considerando-se apenas os critérios de carência de infraestrutura.

Esse déficit está formado por três grandes grupos: coabitação familiar, definida como o caso onde mais de uma família compartilha o mesmo lar; ônus excessivo com aluguéis, representado por famílias com renda até três salários mínimos e que gastam 30\% ou mais com pagamento de aluguel; e domicílios improvisados ${ }^{13}$.

Assim, verificou-se que o déficit se concentrava no meio urbano (67\%) e, neste, o maior componente era a coabitação (77\%), sendo a precariedade concentrada no meio rural (68\%). De mais a mais, $25 \%$ do déficit se encontrava nas Regiões Metropolitanas (RM) e mais da metade dele atingia famílias com renda de até dois salários mínimos (SM). ${ }^{14}$

Entretanto, o indicador déficit habitacional é constantemente questionado quanto a sua capacidade de mensurar a carência de habitação, mesmo quando olhado o conjunto das dimensões que compõem as necessidades habitacionais definidas pela Fundação João Pinheiro em meados de 1990 e utilizadas até hoje:

O trabalho procurou descrever o processo de conformação da metodologia oficial para o cálculo do déficit habitacional como uma necessidade de se estabelecer uma visão governamental e científica para o trato da questão. Embora não tenha incorporado inteiramente a visão empresarial sobre o problema habitacional, o expressivo número que o indicador o apresenta, e a interpretação dada a esse, qual seja, a necessidade de produção de unidades habitacionais, faz com que esse seja bastante útil para os setores interessados. Mesmo a tentativa de destacar a legitimidade dos investimentos em urbanização, acaba sendo negligenciada pelo uso que se faz do indicador, reforçando a dimensão da necessidade de produção. O lançamento do Programa Minha, Casa Minha Vida é exemplo dessa utilização, com respaldo no amplo e quase

\footnotetext{
${ }^{10}$ IBGE 2010

11"O indicador déficit habitacional foi elaborado pela Fundação João Pinheiro para o governo federal em meados da década de 1990, e utilizado ainda hoje com algumas alterações, tal indicador tinha como finalidade orientar as definições da política nacional de habitação em contexto de restruturação institucional do setor. Ao descrever uma trajetória de construção deste mensurador, pôde-se observar as disputas travadas tanto no campo das pesquisas estatísticas quanto naquele da política habitacional". (RUSSO, Endyra de Oliveira. O que o indicador indica? O déficit habitacional no Brasil e as disputas em torno de sua elaboração, em meados dos anos 1990. In CARDOSO, Adauto Lucio Cardoso; ARAGÃO Thêmis Amorim; JAENISCH, Samuel Thomas Jaenisch. Vinte e dois anos de política habitacional no Brasil: da euforia à crise. Rio de Janeiro: Letra Capital: Observatório das Metrópoles, 2017, p. 51)

${ }^{12}$ Fundação João Pinheiro, 2008

${ }^{13}$ Fundação João Pinheiro, 2008

${ }^{14}$ Fundação João Pinheiro, dados colhidos no site http://www.fjp.mg.gov.br/index.php/produtos-eservicos1/2742-deficit-habitacional-no-brasil-3, acessado em 04/08/2017
} 
místico déficit habitacional no Brasil que permanece na casa de 5 milhões de unidades. (RUSSO, 2017, p. 80)

Por outro lado, pelo Censo 2010 (IBGE) a população de pessoas que moram em aglomerados subnormais, alcançou em 2010, 11,4 milhões de pessoas, quase o dobro do número verificado em 2000 (6,5 milhões de pessoas), assim, os residentes em favelas passaram de 3,9\% para 6.9\% aumentando 65\% no número de moradores encontrados em $2000 .{ }^{15}$ Devese frisar que os dados do Censo não demonstram a qualidade das moradias, uma vez que uma parte da população está inserida em moradias com infraestrutura precária, nos assentamentos informais.

Para diminuir esse déficit o governo criou o Programa Minha Casa Minha Vida (PMCMV), e sua implantação está interligada com a polarização entre as lutas pelo direito à cidade e o controle privado sobre a cidade. Para isso, o Estado atua de duas formas, ao mesmo tempo como reorganizador das estruturas institucionais ligadas ao planejamento e, por outro lado, com uma ação diversa dessas estruturas, contrária ao planejamento habitacional.

Para Castells, a produção da moradia resulta da articulação dos três elementos:

O terreno no qual se constrói, os materiais e/ou elementos incorporados na construção e a construção do imóvel propriamente dita, a saber, aplicação da força de trabalho numa dada organização, sobre os materiais de base, para produzir a habitação. As características dos três elementos, suas formas de articulação e sua relação com o mercado determinam uma forma específica do trabalho ou, como diz frequentemente, uma certa "organização da profissão". (CASTELLS, 2014, p. 228)

A estrutura de provisão de moradias se refere à construção, manutenção e distribuição de um estoque, que se forma a partir de diversas formas de provisão de habitação:

promoção privada de casas, apartamentos ou loteamentos, promoção pública de casas ou apartamentos, autoconstrução no lote irregular ou na favela, autopromoção da casa unifamiliar de classe média ou média alta, loteamento irregular, entre outros. Apenas essa abordagem ampla, que toma a moradia como um produto social e histórico, pode explicar o desaparecimento de certas formas de provisão em algumas cidades. (MARICATO, 2009, p. 36)

Assim, em virtude do enorme número do déficit habitacional no Brasil, além do grande número de pessoas que moram em aglomerados subnormais, o governo criou o PMCMV com o intuito de reduzir esses dados e, para a produção dessas moradias, deve-se levar em conta três elementos, o terreno, os materiais e a construção do imóvel, já para o abastecimento das moradias, faz-se necessário além da construção, a manutenção e a distribuição do estoque das moradias.

\footnotetext{
${ }^{15}$ Dados extraídos no site http://censo2010.ibge.gov.br/, acessado em 01/08/2017
} 
O referido PMCMV foi dividido em fases: a fase 1 foi de abril de 2009 a junho de 2011 e a fase 2 vai de junho de 2011 a dezembro de 2014. Também foi dividido em faixas ${ }^{16}$ de rendas, o grupo 1 para aqueles que possuem renda bruta familiar anual até $R \$ 15.000,00$ reais e passam a ter subsídio integral; o grupo 2, para a renda bruta familiar anual de $\mathrm{R} \$ 15.0001$ a $\mathrm{R} \$$ 30.000,00 e tem descontos de 7.610,00 reais do FGTS, subsídio para assistência técnica e equilíbrio econômico financeiro; por fim, o grupo 3, para os outros que possuem renda bruta familiar anual de $\mathrm{R} \$ 30.000,01$ a $60.000,00$ reais e passam a ter subsídio para assistência técnica e equilíbrio.

Em virtude desse programa, o mercado de habitação popular adquire, a partir de 2009, com o MCMV, um mecanismo de produção/financiamento subsidiado pelo governo federal, que atesta a forte dependência desse setor em relação ao poder público (ao Estado), sobretudo quanto ao atendimento das necessidades de moradia dos setores inferiores das classes médias e dos mais podres. (VOLOCHKO, 2015, p. 105)

Assim, o programa, mesmo sendo, formalmente, um único programa, com espectro de atendimento bastante amplo, compreendendo faixas de renda de zero até dez salários mínimos, na prática pode ser visto como uma política com diferentes estratégias de atendimento conforme a faixa de renda da população, em que se diferenciam claramente dois cenários:

um de subsídio público à produção habitacional exclusivamente para a população de mais baixa renda (de zero a três salários mínimos), implementada em parceria com os municípios para demanda por eles indicada a partir de cadastros de beneficiários, com o uso de importantes investimentos públicos a fundo perdido (oriundos do Orçamento Geral da União - OGU, e alocados no Fundo de Arrendamento Residencial - FAR), operados pela Caixa Econômica Federal.

\footnotetext{
16“A Faixa 1 também é atendida por intermédio do Fundo de Desenvolvimento Social (FDS) em operações contratadas com entidades, associações e cooperativas de natureza diversa que tenham se habilitado junto ao Ministério das Cidades e que se disponham a fazer a gestão (direta ou indireta) dos empreendimentos. Trata-se de uma modalidade que incorpora discursos e práticas da produção habitacional autogestionária promovida por governos locais ao longo dos anos 1990 e início dos 2000. Nas Faixas 2 e 3, o financiamento se dá com recursos do FGTS, que se constitui como um "dinheiro mais caro", que exige retorno e cobra juros. Os níveis de subsídio nos financiamentos operados por esse, que é o principal fundo da política habitacional desde sua criação em 1966, vinham sendo aumentados desde 2004, com a aprovação da Resolução 460 do Conselho Curador do FGTS, mediante aportes orçamentários aplicados à Faixa 2 de forma inversamente proporcional à renda familiar: quanto menor a renda, maior o subsídio, até o limite da Faixa 2, considerando ainda os subsídios "indiretos" que decorrem de uma variação nas taxas de juros". (AMORE, Caio Santo. "Minha Casa Minha Vida" para iniciantes. In: Minha casa... e a cidade? avaliação do Programa Minha Casa Minha Vida em seis Estados brasileiros. AMORE, Caio Santo; SHIMBO, Lúcia Zanin Shimbo; RUFINO, Maria Beatriz Cruz (Orgs). Rio de Janeiro: Letra Capital, 2015, p. 22)
} 
A outra parte do PMCMV é destinada às faixas de renda média (até dez salários mínimos), a saber, o chamado segmento econômico. É composta, minoritariamente, por recursos não onerosos (na forma de "descontos" para as faixas até seis salários mínimos) e, principalmente, recursos onerosos (a serem devolvidos na forma de pagamentos de parcelas), advindos do Fundo de Garantia por Tempo de Serviço - FGTS, e com taxa de juros reduzida e maior facilidade de acesso ao crédito. (FERREIRA, 2012, p. 41)

Esse programa é voltado ${ }^{17}$ a dinamizar a economia do Brasil num momento de crise do setor financeiro mundial, como também para diminuir o déficit habitacional por atender a diferentes faixas de rendas, assim, desde que foi lançamento em 2009 é o principal programa habitacional do governo federal, como também, dos governos municipais, que diminuíram suas políticas habitacionais locais para dedicar-se, quase que exclusivamente, ao programa federal.

Por outro lado, a política do programa divide-se em, de um lado, subsídio público, à produção habitacional, para a população de baixa renda (em parceria com os Municípios), com a utilização de investimentos públicos, operados pela Caixa e, em contrapartida, destinado à renda média, denominada, segmento econômico, os descontos, recursos onerosos do FGTS, redução de juros e acesso ao crédito.

Para atingir os objetivos do programa, o governo federal deve exigir dos agentes promotores - o operador financeiro, construtoras e municípios -, a observação da qualidade arquitetônica e urbanística, além de incentivar os municípios, responsáveis pela gestão do uso e ocupação do solo, para a aplicação dos instrumentos do Estatuto da Cidade, de forma a evitar os impactos urbanos relatados no capítulo anterior. Deve também promover a integração entre as esferas de governo na implementação das políticas públicas. (FERREIRA, 2012, p. 48)

O PCMV prioriza que os investimentos imobiliários sejam feitos em áreas com infraestrutura e transporte coletivo, escolas, postos de saúde, mas, na prática, conforme pesquisas que serão citadas, o que se detectou foi o descolamento da população para a periferia sem acesso aos serviços públicos básicos do cidadão, assim, primeiro cria-se a moradia, depois realiza-se o investimento em infraestrutura. Cumpre frisar que a responsabilidade, por tudo isso, também é do Município, gestor do uso e ocupação do solo, como também responsável na aplicação dos instrumentos urbanísticos para efetivar a moradia.

\footnotetext{
17“Art. $1^{\circ} \mathrm{O}$ Programa Minha Casa, Minha Vida - PMCMV tem por finalidade criar mecanismos de incentivo à produção e aquisição de novas unidades habitacionais ou requalificação de imóveis urbanos e produção ou reforma de habitações rurais, para famílias com renda mensal de até $R \$$ 4.650,00 (quatro mil, seiscentos e cinquenta reais) e compreende os seguintes subprogramas: I - o Programa Nacional de Habitação Urbana (PNHU); II - o Programa Nacional de Habitação Rural (PNHR)" (BRASIL. Lei. 11.977/2009. Disponível a partir do site <http:// www.planalto.gov.br)
} 
Em contrapartida, as grandes empresas do ramo de construção de habitação percorrem todo o ciclo do produto imobiliário pois são proprietárias das terras, incorporadoras, construtoras e vendedoras, necessitando de produção em escala e com o mesmo padrão, além do capital financeiro e a participação do Estado.

Essa concentração da produção habitacional em grandes empresas construtoras já vinha se esboçando, antes do lançamento do PMCMV, com o fortalecimento do segmento econômico:

Desde o início da década de 1990 - particularmente, desde 1994, com o plano de estabilização da economia (Plano Real) -, uma série de mecanismos regulatórios, institucionais e produtivos acabaram favorecendo a atuação de agentes privados e a ampliação do protagonismo do mercado na política habitacional brasileira. Tais mecanismos possibilitaram a constituição de um nicho bastante lucrativo para grandes empresas ao fomentar a incorporação e a construção de unidades habitacionais com valores de até USD 100 mil e destinadas a famílias que somam renda suficiente para acessar tanto os subsídios públicos (famílias de baixa renda) quanto o crédito imobiliário (famílias de média renda). (SHIMBO, 2017, p. 311)

Sobre a produção de moradias e o lucro das construtoras o "Observatório das Metrópoles" avaliou que de 2006 a 2010, ela multiplicou por 16 a sua produção e bateu o teto de produção de mais de 45 mil unidades em 2010. Já o lucro líquido foi aumentado em 4310\%, entre 2006 e 2011, alcançando o patamar de R\$ 760 milhões. Esse ano, 2011, foi um ponto de virada no desempenho operacional da empresa na medida em que a partir daí houve uma redução em quase todos os seus indicadores: em 2013, a produção baixou para aproximadamente 26 mil unidades/ano e seu lucro líquido caiu para aproximadamente $R \$ 420$ milhões (ou seja, uma redução de quase 50\% em relação a 2011). (SHIMBO, 2017, p. 312)

Esse êxito econômico das construtoras, sobretudo até 2011, pode ser explicado pela:

sua estrutura de produção strictu sensu (desde o canteiro de obras até as instâncias de gestão e decisão da empresa), pelo seu vínculo com o Estado e com o capital financeiro, e também pela sua estratégia de controle de produção do espaço urbano. Ou seja, essa forma específica de produção da habitação - a habitação social de mercado - possibilitou ganhos de escala, de lucro e de abrangência territorial, estabelecendo uma conexão inédita na estrutura de provisão habitacional no Brasil, na qual as decisões tomadas no interior da empresa impactam, significativamente, na produção do espaço urbano, muitas vezes, sem qualquer intermediação do poder público ou de agência de regulação. (SHIMBO, 2017, p. 311) 
Por outro lado, com a abertura de capital de 24 empresas do setor imobiliário e uma forte inversão de capital externo, iniciou-se uma avassaladora procura por terrenos, num processo especulativo que chegou a ser chamado, entre 2007 e 2008, de boom imobiliário:

Frente à necessidade de ampliar seu mercado, muitas empresas tradicionalmente voltadas para a classe alta e média alta criaram subsidiárias especializadas em produtos mais baratos, dirigidos à baixa classe média, segmento que cresceu fortemente com a política econômica e salarial do governo Lula, mas com renda ainda insuficiente para adquirir uma moradia do mercado privado. A viabilização do crédito imobiliário privado, sem subsídio, para esse segmento é decisiva para a questão habitacional. (SHIMBO, 2017, p. 312)

O "Observatório das Metrópoles" detectou que quando a empresa construtora abriu seu capital na Bolsa de Valores, em 2007, o montante de recursos captado foi destinado para a aquisição de terrenos e para a incorporação de novos empreendimentos (45\% do total):

Para tanto, executivos da empresa saíram percorrendo sete Estados brasileiros em busca de boas oportunidades de negócio. Como resultado dessa busca, se seu banco de terrenos, em 2006, estava avaliado em aproximadamente 1,5 bilhão de reais, com capacidade para construção de 11.700 unidades, um ano depois ele aumentou em 10 vezes o seu valor e o seu respectivo número de unidades, passando para $\mathrm{R} \$ 10$ bilhões e mais de 107 mil unidades. Em 2012, esse valor estava em R\$ 21,8 bilhões, correspondente a 173 mil unidades, num total de 8,1 milhões de metros quadrados de área útil comercializável. (SHIMBO, 2017, p. 318)

Acontece que o PMCMV entra em funcionamento justamente quando algumas destas empresas passaram a ter dificuldades, principalmente em decorrência da crise hipotecária norte-americana em 2008. O início das ações do PMCMV representou para o setor imobiliário uma oportunidade de reconcentração e fusão de grandes empresas que tiveram na abertura de créditos e linhas de financiamentos por parte do governo federal a oportunidade de garantirem um novo ciclo de acumulação. (OLIVEIRA, 2017, p. 335)

Ao mesmo tempo que se buscava uma solução para a crise do setor habitacional através do PMCMV, promovia-se um progressivo afastamento do Estado da resolução das questões relativas à problemática habitacional. Este afastamento se deu, em parte, pela entrega das decisões da política habitacional ao setor privado, que priorizou atuar na oferta de moradias com formas e modelos construtivos massificados que buscavam a maior lucratividade. (OLIVEIRA, 2017, p. 335)

Assim, percebe-se que o PMCMV tem como finalidade a diminuição do déficit habitacional, através de uma ação conjunta dos agentes promotores, operadores financeiros, construtoras e Município. Entretanto, o programa entrega as decisões da política habitacional 
para o setor privado, utilizando fundos públicos nesse setor, o que implica exclusão social, com o deslocamento da população para a periferia e, ganhos fundiários, para as construtoras com a construção das "habitações sociais".

\section{O PMCMV A SEGREGAÇÃO URBANA E A MERCANTILIZAÇÃO DA MORADIA: CONSEQUENNCIAS DIRETAS PARA OS MORADORES E INDIRETAS PARA A SOCIEDADE}

Por outro viés, o Estado pode participar diretamente na produção das moradias, como também pode financiar e contratar a construção. Ele é ainda, em geral, o agente regulador da terra, das relações trabalhistas, das regras do financiamento privado, além de poder promover a implantação da infraestrutura e abrir novos espaços para o investimento imobiliário privado em acordo com proprietários de terra. (MARICATO, 2009, p. 42)

Os Estados têm participação importante na aplicação das leis sobre uso e ocupação do solo, principalmente nas áreas de jurisdição estadual, como as áreas de proteção ambiental (APAs, APPs, Mananciais). Respondem pela aprovação dos projetos localizados nessas áreas sensíveis e de projetos de grande porte, com impacto em mais de um município. São muitas vezes responsáveis pela infraestrutura de transporte, saneamento, iluminação e, por isso, têm interferência em empreendimentos de maior porte ou em áreas ainda não atendidas pelos serviços urbanos. (FERREIRA, 2012, p. 48)

No mesmo sentido, os Municípios são hoje responsáveis pela elaboração dos planos diretores e das leis de uso e ocupação do solo urbano e, portanto, têm participação importante no mercado de terras e localização dos empreendimentos habitacionais, respondem pela aprovação dos projetos e definem as medidas mitigadoras a serem executadas pelo agente promotor, caso haja necessidade em função dos impactos provocados pelo empreendimento em aprovação. (FERREIRA, 2012, p. 48)

Sabe-se que a prerrogativa das políticas territorial, urbana e habitacional é, desde 1988, municipal, assim, no máximo, um programa de financiamento federal (ou estadual) poderá estabelecer algumas diretrizes condicionais, com a esperança que os municípios as acatem, mas não é da competência de um programa de financiamento determinar a localização de empreendimentos, nem a política fundiária municipal:

O fato é que é das prefeituras a responsabilidade de garantir oferta de terra urbanizada bem localizada também aos mais pobres, de estabelecer 
normas de qualidade urbanística e edilícia, de prover infraestrutura, equipamentos e serviços. Desde 1988 devem elaborar Planos Diretores que supostamente deveriam dar diretrizes para isso, e desde 2001, com o Estatuto da Cidade, elas dispõem de um conjunto de instrumentos legais para, por exemplo, combater a retenção de terras ociosas em áreas centrais, para fazer estoques fundiários para fins de moradia, para regularizar áreas informais. Instrumentos que poderiam lhes dar a força reguladora necessária para produzir HIS em áreas mais centrais, ainda mais quando aparecesse alguma política de financiamento mais substanciosa. (FERREIRA, 2015, p. 8)

Nesse sentido, a Lei 11.977/2009 (PMCMV) elencou os requisitos para a implantação de empreendimentos do Programa Nacional de Habitação Urbana (PNHU), em seu artigo 5o A:

I - localização do terreno na malha urbana ou em área de expansão que atenda aos requisitos estabelecidos pelo Poder Executivo federal, observado o respectivo plano diretor, quando existente;

II - adequação ambiental do projeto;

III - infraestrutura básica que inclua vias de acesso, iluminação pública e solução de esgotamento sanitário e de drenagem de águas pluviais e permita ligações domiciliares de abastecimento de água e energia elétrica; e

IV - a existência ou compromisso do poder público local de instalação ou de ampliação dos equipamentos e serviços relacionados a educação, saúde, lazer e transporte público. ${ }^{18}$

Entretanto, com o lançamento e a crescente hegemonia do Programa Minha Casa

Minha Vida, verifica-se um retrocesso das administrações locais, que:

com a facilidade oferecida pelo novo Programa do Governo Federal, passam a orientar-se com maior vigor na direção de transferir as famílias para áreas distantes de seus locais de origem. Essa facilidade decorre do fato de que os novos conjuntos são realizados praticamente sem recursos municipais, cabendo às administrações locais o papel de realizar cadastros e inaugurações, o que Ihes aumenta o capital político, sem necessidade de alocar recursos orçamentários. Com isso, a organização da política habitacional nos dois eixos que a caracterizavam parece encontrar-se ameaçada, e a política de urbanização de assentamentos precários começa a ser subordinada à lógica das remoções e do Programa Minha Casa Minha Vida. As consequências desse processo recaem sobre os moradores, inviabilizando o seu acesso (ainda que precário) às fontes de trabalho e renda, às redes de sociabilidade local e os moradores ainda têm que arcar com os custos - sociais e monetários - da vida em condomínio. Sem dúvida alguma, está sendo criado um passivo social que já apresenta hoje problemas graves e que terá consequências mais sérias no futuro. (CARDOSO, 2017, p. 225)

Percebe-se, que é de competência de o Poder Público local elaborar os planos diretores e as leis de uso e ocupação do solo urbano, participando do mercado de terras e da localização do empreendimento, da política fundiária municipal, como também, da instalação dos serviços

\footnotetext{
${ }^{18}$ BRASIL. Lei. 11.977/2009. Disponível a partir do site <http:// www.planalto.gov.br
} 
de educação, saúde, lazer e transporte público. Assim, cabe ao Município ofertar a terra urbanizada e bem localizada, além de estabelecer os instrumentos urbanísticos, infraestrutura, equipamentos e serviços.

Entretanto, como detectado nas pesquisas trazidas nesse artigo, os empreendimentos do PMCMV não atendem a esses requisitos, ocasionando uma segregação, com a transferência das famílias para áreas distantes de seu local de origem, o que implica em inviabilidade ao acesso às fontes de trabalho e renda, às redes de sociabilidade local, além dos altos custos em virtude de morar em condomínios.

O PMCMV se estrutura sobre um modelo de mercantilização do bem que se propõe a ofertar a moradia a partir da transferência (ou aquisição) da propriedade do bem:

Um primeiro impacto sobre a sustentabilidade do programa diz respeito ao fato de que, uma vez transferido, o bem tem um valor de mercado, o que permitiria ao beneficiário capitalizar o valor monetariamente, transferindo-o para outra pessoa. Isso pode significar - e ocorre frequentemente - que essa transferência implique em um desvio em relação aos objetivos sociais do programa, já que acabariam sendo beneficiadas pessoas de faixas de renda mais elevadas, que se aproveitariam dos subsídios promovidos. Por conta desse problema, o programa estabelece um conjunto de limitações visando evitar transferências prematuras, mas há sempre o risco de transações realizadas informalmente. (CARDOSO, 2017, p. 42-43)

Um outro problema, mais sério, diz respeito ao fato de que uma política habitacional dotada de amplos recursos de subsídios e financiamentos direcionados tem como consequência imediata um aquecimento do mercado e uma tendência à elevação dos preços da terra, cuja oferta tem pouca elasticidade em relação à demanda:

A elevação dos preços da terra, aliada, ainda, ao aumento da demanda por insumos para a produção, gera um crescimento dos custos de produção significativamente superior à valorização média de outros bens e à inflação. Para enfrentar esse problema, a proposta original de política habitacional presente no Projeto Moradia colocava em plano relevante à adoção de medidas de controle da valorização e da especulação com a terra. Isso, todavia, não aconteceu, o que levou a que a cada edição do PMCMV se fizessem reajustes significativos dos valores teto de produção, implicando em um crescimento dos gastos públicos com subsídios superior ao crescimento do volume de produção. Este foi um dos fatores que pode ter levado ao sucessivo adiamento do lançamento da terceira edição do programa, já que o governo, em 2015, havia adotado medidas importantes de contenção dos gastos e de ampliação dos juros. (CARDOSO, 2017, p. 42-43)

Por outro lado, a especulação imobiliária provém, essencialmente, da penúria das moradias, que ela contribui para reforçar: 
Com efeito, numa situação relativamente equilibrada entre oferta e demanda das moradias, a especulação recai apenas sobre certas zonas (centro da cidade, zonas de boa densidade etc.) e não sobre o conjunto do aglomerado ou mesmo sua periferia. Portanto, se do ponto de vista de uma política de habitação, o primeiro obstáculo a vencer é a especulação imobiliária (pois uma vez que ela aparece, seu mecanismo absorve todos os orçamentos-moradias de que se pode dispor), ela não está na base da enorme defasagem entre construção e necessidade de moradias. As razões fundamentais desta defasagem devemos encontrar no próprio processo de produção. (CASTELLS, 2014, p. 230)

Por tudo isso, o PMCMV trouxe um modelo de mercantilização do bem, uma vez que todo bem tem um valor de mercado o que permite ao beneficiário capitalizar o valor monetariamente, transferindo-o a outra pessoa, quando a venda for possível. Por outro lado, ocasiona o aquecimento do mercado e a elevação dos preços da terra, assim, a elevação os preços da terra junto com o aumento da demanda por insumos para a produção, gera um crescimento dos custos de produção maior do que a valorização média dos outros bens e à inflação. Por fim, gera a especulação imobiliária sobre certas zonas, tais como centro da cidade e zonas de boa densidade.

Entretanto, na prática, defende Ferreira, que o programa acentua o processo de segregação dos mais pobres em conjuntos periféricos e estigmatizados. As casinhas enfileiradas, sem nenhuma qualidade arquitetônica e construtiva, que pouco ou nada se integram à cidade, com poucos equipamentos e implantação paisagística monótona, são hoje o modelo de urbanização predominante no país. (FERREIRA, 2015, p. 6)

Essa segregação urbana, conforme Castells, é a tendência à organização do espaço em zonas de forte homogeneidade social interna e com intensa disparidade social entre elas, sendo esta disparidade compreendida não só em termos de diferença, como também de hierarquia:

Existe, por um lado, a interação entre as determinações econômicas, política, ideológica, na composição do espaço residencial; por outro lado, que existe um reforço da segregação, um transbordamento de seus limites tendenciais ou modificação dos fatores de ocupação do solo, segundo a articulação da luta de classes no local de residência, por exemplo através da comunidade de grupos pelas fronteiras ecológicas. (2014, p. 250)

A segregação urbana é expressão, em nível da reprodução da força de trabalho, das relações complexas e mutáveis que determinam suas modalidades; assim, não há espaço privilegiado antecipadamente, em termos funcionais, sendo o espaço definido e redefinido segundo a conjuntura da dinâmica social. Isso quer dizer concretamente que a estrutura do espaço residencial sofre as seguintes determinações: 
Em nível econômico, ela obedece à distribuição do produto entre os indivíduos e à distribuição específica deste produto que é a moradia. Este fator está na base do conjunto do processo.

...

Em nível político-institucional, a "democracia local" tende a reforçar as consequências da segregação, praticando uma política de serviços em função dos interesses da fração dominantes de cada unidade administrativa.

....

Em nível ideológico, a segregação residencial ocorre por dois movimentos bem diferentes. (FERREIRA, 2015, p. 262-263)

Pelo exposto, já repetimos, diversas vezes, que a utilização de fundos públicos para a construção de habitações em larga escala de forma dissociada de uma política de gestão e de terras tem como consequência a exclusão social e ganhos fundiários. Além disso, o PMCMV funda-se na noção de casa como mercadoria e não como direito fundamental que é, adotando a produção nova como modelo único de produção, desvinculada do urbanismo e dos direitos à cidade. Por fim, esse programa gera a segregação, uma vez que o espaço é definido pela dinâmica social e sua estrutura é determinada em nível econômico, político-institucional e ideológico.

Nesse viés, os conjuntos residenciais, levantados com dinheiro público, mas por firmas privadas, para as classes médias baixas e os podres:

Situam-se quase invariavelmente nas periferias urbanas, a pretexto dos preços mais acessíveis dos terrenos, levando, quando havia pressões, a extensões de serviços públicos como luz, água, às vezes a esgotos, pavimentação e transportes, custeados, também, com os mesmos recursos. É desse modo que o BNH contribui para agravar a tendência ao espraiamento das cidades e para estimular a especulação imobiliária. A construção de um conjunto residencial, e a consecutiva dotação de infraestruturas, valoriza os terrenos ao derredor, estimulando os proprietários a uma espera especulativa. Produzem-se novos vazios urbanos, ao passo que a população necessitada de habitação, mas sem poder pagar pelo seu preço nas áreas mais equipadas, deve deslocar-se para mais longe, ampliando o processo de periferização. (SANTOS, 2013, p. 124)

Com o PMCMV, o Estado canaliza os recursos públicos para aquela produção/acumulação capitalista ocupada com a satisfação de parte das necessidades da reprodução da força de trabalho: a moradia, mas sobretudo para reproduzir os capitais presentes na sua realização como mercadoria. Após cinco anos de andamento do programa, as críticas convergem para o seguinte ponto: quando se observa o quadro do déficit habitacional no Brasil, vê-se que $89,6 \%$ desse déficit diz respeito às famílias com renda mensal entre 0 e 3 
salários mínimos, faixa para a qual têm sido contratados menos financiamentos. (VOLOCHKO, 2015, p. 113)

No mesmo caminho, Harvey releva o papel múltiplo que os subsídios estatais para habitação representam para a indústria da construção de moradias:

Em primeiro lugar, os subsídios do Estado para a indústria constituem um suporte Keynesiano para a economia e um regulador importante do crescimento. Em segundo lugar, a posse de uma casa de moradia é visualizada como um meio pelo qual as reivindicações do trabalhador foram divididas em preocupações relativas ao trabalho e preocupações referentes à qualidade de vida, em que esta recebe a maior ênfase da parte do Estado (socialização do capital). Finalmente, o fato de uma porção importante da classe trabalhadora possuir uma propriedade quebra ainda mais a consciência de classe e faz com que o grupo de proprietários da classe trabalhadora se alie aos capitalistas e contra aqueles que vivem de aluguel. (GOTTDIENER, 2016, p. 137)

Assim, o setor da construção civil transborda os investimentos do Programa MCMV para os demais setores do mercado, visto que há uma complexa inter-relação entre os agentes econômicos por meio da cadeia produtiva do setor de habitação, ligando desde fornecedores de matérias-primas, prestações de serviços, insumos, entre outros e, ainda, atividades que trabalham os produtos imobiliários prontos, como hotéis, aluguéis, administração e consultorias. (PERREIRA, 2016, p. 345)

Por tudo isso, detecta-se que a utilização dos fundos públicos por parte do Poder Público para o Programa Minha Casa Minha Vida faz com que o setor privado (especialmente as construtoras), se beneficiem dos subsídios públicos, além de canalizar esses recursos para a produção/acumulação capitalista, fazendo com que haja o crescimento das construtoras desse setor que transbordam os investimentos públicos para outros setores do mercado.

Por outro lado, não é objeto dessa tese avaliar o Programa Minha Casa Minha Vida, mas analisar as pesquisas científicas já realizadas, como também a doutrina especializada no tema, para podermos compreender melhor as consequências que o programa trouxe em relação ao déficit habitacional e entender sua relação com as construtoras, Caixa Econômica Federal e Municípios, além de detectar a qualidade nas produções das moradias.

Volochko, analisando os empreendimentos do PMCMV, percebe que a tecnologia construtiva de muitos empreendimentos é voltada para a otimização da construção, utilizando formas e materiais pré-fabricados que permitam uma montagem mais rápida e padronizada. A aprovação desses grandes condomínios, que abrigam milhares de famílias, junto ao poder público costuma ser marcada por uma maior permissividade dos órgãos municipais, a despeito do fato de que nos empreendimentos financiados pela Caixa Econômica Federal, como Minha 
Casa Minha Vida, existem critérios e normas construtivas que devem ser fiscalizadas por um corpo de engenheiros. (2015, p. 109)

O mesmo autor nota que os novos moradores dos condomínios habitacionais produzidos nesse processo são procedentes em sua maioria de espaços já periféricos, embora de periferias menos distantes, o que leva a crer que existe uma sujeição desses grupos a um maior afastamento explicada pela tentativa de tonarem-se proprietários formais de suas casas, o que apenas pode ocorrer em espaços distantes e menos valorizados. (2015, p. 106)

No mesmo trilhar, Ferreira defende que a produção pública hoje, em regra geral, ainda não é boa, do ponto de vista arquitetônico:

Reproduz os modelos do período do BNH, com conjuntos de milhares de casas idênticas, de péssima arquitetura. A habitação popular tornou-se sinônimo de baixa qualidade. Deixa-se também contaminar pela má qualidade arquitetônica da produção privada para a renda média, do segmento econômico. Parece paradoxal, em um país em que a eficiência do setor privado é geralmente muito festejada, que hoje o setor público para baixa renda produza - mesmo que em quantidade ainda muito pequena - exemplos de conjuntos habitacionais com mais qualidade do que os produzidos pelo mercado privado do segmento econômico. (2012, p. 56)

Além disso, segundo Rolnik entende que o PMCMV não contribuiu para qualificar as áreas onde os empreendimentos são implantados e reduzir sua precariedade

pois a forma do condomínio fechado e murado, reproduz enclaves fortificados, fragmentado e desconexo, não transformando ou qualificando. Essa forma de condomínio exige dos moradores o pagamento de uma taxa mensal de manutenção, que em muitos condomínios pesquisados existe a inadimplência. Existem também empreendimentos dominados por grupos ligados ao tráfico de drogas e/ou milícias. Por fim, dados demonstram como a violência está fortemente presente nos empreendimentos. (2015, p. 314-316)

Por outro lado, argumenta Rizek que o PMCMV acaba por se constituir em profunda despolitização da questão da moradia e, sobretudo, do acesso à cidade:

A construção da demanda dos grupos candidatos a beneficiários empreendimentos, se dá, sobretudo, através de relações de âmbito privado, relações de parentesco ou amizade, oriundas de relações pessoais, e é raro entre os grupos pesquisados encontrar alguém com nítida trajetória de luta no movimento de moradia, com tempo de participação que exceda o tempo de formação do grupo e assinatura do contrato, são relações que acabamos por denominar "associativismo de ocasião". (2015, p. 117)

Por tudo isso, percebe-se que as moradias construídas através do PMCMV têm uma tecnologia voltada à otimização da construção, com a montagem rápida e padronizada e, do ponto de vista arquitetônico, as casas são idênticas, péssima arquitetura e baixa qualidade. Por 
outro lado, a forma como são construídos os condomínios, fechado e murado, fragmentado e desconexo, tornam-se, sem qualificação. Por fim, existe a despolitização da questão da moradia, uma vez que os beneficiários são escolhidos através de relações privadas, quais sejam, parentesco ou amizade.

O "Observatório das Metrópoles" detectou que entre 2004 e 2005, os financiamentos eram provenientes, basicamente, do Programa Crédito Associativo (operacionalizado pela CAIXA) e do financiamento contraído diretamente com a construtora (que correspondia a aproximadamente $60 \%$ do total dos financiamentos). Entre 2006 e 2008, surge o financiamento bancário, contraído junto aos bancos comerciais, e que passa a ser majoritário nesse período. Por fim, entre 2009 e 2013, há o aumento considerável da participação do Crédito Associativo, que passa a abarcar em torno de $80 \%$ dos financiamentos contraídos. (SHIMBO, 2017, p. 322)

Além disso, por ser um programa de financiamento e não uma política habitacional e urbana, quem assegura a fiscalização dos parâmetros de qualidade arquitetônica e urbanística é um banco, a Caixa:

cuja vocação, evidentemente, não é bem essa, e cujo poder sobre os municípios no que tange à organização do território também é limitado, apesar da boa vontade de seus técnicos, e de seus escritórios regionalizados.

Condicionam as aprovações de empreendimentos por critérios técnicos de projeto e urbanismo que muitas vezes se mostram rigorosos demais em quesitos pouco essenciais, mas pouco efetivos em aspectos importantes para a qualidade urbanística. Somam-se aos critérios da Caixa (como por exemplo o chamado Selo Azul) algumas outras tentativas de parametrização, como novas normas de desempenho dos materiais de construção, a exigência de projetos universais (que possam ser convertidos em projetos acessíveis) que, de alguma forma, ajudam a melhorar um pouco a qualidade dos projetos. Ainda assim, estamos longe de uma mudança real de qualidade. (FERREIRA, 2015, p. 10)

Por outro lado, a gestão operacional dos recursos destinados à concessão da subvenção do PNHU é efetuada pela Caixa Econômica Federal e os Ministros de Estado das Cidades e da Fazenda fixarão, em ato conjunto, a remuneração da Caixa Econômica Federal pelas atividades exercidas no âmbito do PNHU. ${ }^{19}$

No mesmo sentido, é limitado o poder político da Secretaria Nacional de Habitação na condução do programa, face à Caixa Econômica Federal, que o opera financeiramente, ou mesmo a outras secretarias do Governo Federal, e as iniciativas tomadas têm pouco efeito:

mesmo limitando os condomínios a 300 unidades, nada impede as construtoras de, com a complacência interessada dos municípios,

\footnotetext{
${ }^{19}$ Art. 9o (BRASIL. Lei. 11.977/2009. Disponível a partir do site <http:// www.planalto.gov.br)
} 
enfileirarem dez ou mais condomínios, produzindo conjuntos das 3 mil unidades. A determinação de localizar os empreendimentos em áreas de extensão urbana não impede que câmaras municipais, em um exemplo folclórico mas indicativo das relações ainda arcaicas que regem a ordenação do território, denominem como tal a distante fazenda do genro do primo do filho do prefeito, e assim por diante. Além do mais, as desigualdades regionais brasileiras produzem situações pitorescas: em pequenas cidades de regiões muito pobres, satisfazer as exigências de infraestrutura - como asfalto, luz, linhas de ônibus - significa transformar o empreendimento do PMCMV em um bairro mais luxuoso do que as áreas "nobres", porém paupérrimas, da cidade. (FERREIRA, 2015, p. 10)

Em contrapartida, defende Ferreira que dar moradia não significa apenas dar teto, mas sim dar "cidade", com tudo que isso implica: mobilidade, acesso ao comércio, aos empregos, a equipamentos e serviços, espaços públicos de qualidade, etc. Como é quase impossível, e extremamente custoso, garantir essa equação urbana em bairros distantes e desprovidos de tudo, onde geralmente se localizam os conjuntos para os mais pobres, ou seja, resolver "de verdade" o problema da habitação significaria tornar nossas cidades democráticas, alterando radicalmente sua lógica de produzir segregação, desigualdade e intolerância. (2015, p. 5)

Assim, quando se menciona o direito de habitar, a cidade não se pode reduzir o tema ao acesso a uma unidade residencial em um bloco de apartamentos ou a uma casa em conjunto habitacional, edificações geralmente produzidas em série pela racionalidade mercantil estatal e privada, é preciso valorizar experiências mais ricas de habitação em curso nas favelas e periferias, elevando-as à condição de direito, direito à morada:

A concepção de morada aqui destacada significa a inserção de pessoas em relações de pertencimento, tangíveis e intangíveis, que estabelecem horizontes de sentido do território em uso, uma vez que reúne recursos sociais (escolas, postos de saúde, creches), recursos afetivos (amores, paixões, parentescos, amizades) e recursos simbólicos (igrejas, bares, blocos de carnaval, escolas de samba, campos de futebol, terreiros de umbanda e de candomblé), mobilizados e compartilhados por indivíduos, famílias e grupos sociais, no processo de atribuir significado às suas exigências e de sua tenaz permanência na cidade. (BARBOSA, 2017, p. 183)

Por fim, o CNPq junto com o Ministério das Cidades, lançou em 2012, edital de pesquisa para avaliar o PMCMV, do qual resultou 11 equipes contempladas que formaram a Rede Cidade e Moradia e avaliaram empreendimentos de 22 municípios em 6 Estados: Pará, Ceará, Rio Grande do Norte, Minas Gerais, Rio de Janeiro e São Paulo, e concluíram em outra pesquisa publicada pelo "Observatório das Metrópoles", publicada em 2015:

a) como são as construtoras - em sua relação com a Caixa - que definem o projeto e sua localização, tem prevalecido no programa um padrão de produção com fortíssima homogeneização das soluções de projeto 
arquitetônico e urbanístico e das técnicas construtivas, independentemente das características físicas dos terrenos ou das condições bioclimáticas locais; b) os Municípios permitem a construção dos empreendimentos em localizações mais baratas, como por exemplo, em zonas rurais englobadas por alterações nos perímetros urbanos, que reproduzem um padrão de cidade segregada e sem urbanidade, pois são mal servidas por transporte, infraestrutura ou oferta de serviços urbanos adequados ao desenvolvimento econômico e humano; c) os processos de seleção da demanda feito por meio de cadastro das prefeituras nem sempre são transparentes; d) programa habitacional que atende prioritariamente aos interesses do setor privado, sem vínculos necessários com uma política urbana e fundiária, que estima o aumento dos preços dos imóveis na cidade e tem gerado péssimas inserções urbanas e segregação social, e) o programa baseia-se numa produção padronizada e em larga escala, desarticulada das realizadas locais, mal inserida e isolada da cidade, a partir de um modelo de propriedade privada condominial. (RUFINO, 2015, p. 419-422)

Assim, desde o início dos anos 80, nunca as perspectivas foram tão boas para o enfrentamento em larga escala do problema habitacional, inclusive para a baixa renda. No entanto, se não forem tomadas as medidas necessárias no âmbito do planejamento habitacional, da regulação urbana, da cadeia produtiva da construção civil e da capacitação institucional, o crédito farto poderá gerar um boom imobiliário, mas, novamente, os setores de baixa renda poderão ficar de fora, reproduzindo-se o tradicional processo de exclusão territorial. (BONDUKI, 2015, 104)

Por tudo que foi exposto, detecta-se que os empreendimentos construídos através do PMCMV utilizam tecnologia voltada à otimização da construção, produzindo uma moradia que não é boa arquitetonicamente, não qualificando as áreas dos empreendimentos e, constituindo, uma despolitização da questão da moradia. Por fim, as moradias construídas pelo programa estão desvinculadas das características físicas e climáticas locais; suas localizações são ruins; sem transporte, infraestrutura e serviços urbanos; a seleção dos beneficiários não é transparente; atende ao setor privado desvinculado da política urbana e fundiária; além de ser desarticulado com as realidades locais.

\section{CONCLUSÃO}

Por tudo isso, pode-se identificar que o direito à cidade engloba o direito à moradia e, este, é o mais importante efeito jurídico do princípio da função social a propriedade urbana, inserido em nossa constituição. No entanto, para disciplinar as diretrizes da política urbana brasileira, ou seja, o conteúdo do princípio da função social da propriedade urbana, foi criado o 
Estatuto da Cidade. Acontece que, após análise de pesquisas, anteriormente realizada (2014), percebeu-se que dos 5.570 municípios do Brasil, apenas 8 regulamentaram esse diploma.

No mesmo sentido, estudou-se o plano diretor, instrumento jurídico que fixa os requisitos da função social da propriedade urbana por cada município e percebeu-se que os planos são elaborados sem referência ou marcos de planejamento e não são devidamente atualizados e regulamentados, o que compromete a aplicação do princípio constitucional e, consequentemente, a concretização do direito social à moradia.

Compreendeu-se a Política Nacional de Habitação (PNH) como um plano que busca equacionar as necessidades habitacionais do Brasil, através de ações públicas e privadas, no prazo de 15 anos. Essa PNH conta com a ação conjunta do Plano Nacional da Habitação (PlanHab) que tem como objetivo a mobilização de recursos para reduzir o déficit habitacional.

No entanto, não foi localizada uma pesquisa científica específica para detectar se o PMCMV acompanha as diretrizes do PlanHab, entretanto, a doutrina afirma que o PMCMV não adota o conjunto de estratégias que o PlanHab julga necessário para diminuir o déficit habitacional no Brasil, como também, que o programa ignorou as premissas e os debates em torno do plano que vinha sendo discutido.

Por fim, a respeito da questão da moradia e o Programa Minha Casa Minha Vida (PMCMV), preliminarmente, analisou-se as soluções marxistas para acabar com a escassez de moradia e, percebeu-se, que se deve eliminar a espoliação da classe trabalhadora pela classe dominante, além da abolição do modo de produção capitalista e a apropriação dos meios de vida e trabalho pela classe trabalhadora.

Identificou-se que a criação das favelas se tornou uma alternativa para a falta de habitação e, analisando dados da Fundação João Pinheiro (2008), detectou-se que o déficit habitacional no Brasil é de 5,8 milhões de moradias. Por outro lado, pelo Censo - IBGE (2010), a população de pessoas que moram em aglomerados subnormais é de 11,4 milhões de pessoas.

Com a finalidade de equilibrar esses dados, o governo criou o PMCMV, no entanto, o programa entregou as decisões da política habitacional para o setor privado, ocasionando ganhos fundiários para as construtoras. Estudou-se a responsabilidade dos municípios em ofertar a terra urbana e bem localizada, além de estabelecer os instrumentos urbanísticos, infraestrutura, equipamentos e serviços para a efetivação do PMCMV.

Entretanto, como detectado nas pesquisas trazidas nesse artigo, os empreendimentos do PMCMV não atendem a esses requisitos, ocasionando uma segregação, com a transferência das famílias para áreas distantes de seu local de origem, o que implica em inviabilidade ao 
acesso às fontes de trabalho e renda, às redes de sociabilidade local, além dos altos custos em virtude de morar em condomínios.

Cumpre relembrar que não foi objeto deste artigo realizar uma pesquisa, específica, sobre o Programa Minha Casa Minha Vida (PMCMV), mas analisarmos diversas pesquisas já realizadas, principalmente as publicadas pelo "Observatório das Metrópoles", além da doutrina especialista no tema. Assim, os dados e as conclusões desta, sobre o PMCMV, tiveram esses dois fundamentos.

Por outro lado, a mercantilização da moradia, tão debatida pela doutrina marxista foi detectada no PMCMV, uma vez que toda habitação tem um valor de mercado, o que permite ao proprietário do bem capitalizar o valor monetariamente, transferindo-se a outra pessoa, quando possível.

O referido programa ocasionou o aquecimento do mercado e a elevação do preço da terra, no entanto, com a elevação dos preços da terra em conjunto com o aumento da demanda por insumos para a produção, gerou um crescimento dos custos de produção maior do que a valorização média dos outros bens e a inflação. Gerou, também, a especulação imobiliária sobre determinadas zonas, tais como centro da cidade e zonas de boa densidade.

Detectou-se que a teoria dos investimentos públicos do Estado em favor do setor privado também está presente do PMCMV, uma vez que existiu a utilização de fundos públicos, por parte da União, para a construção de habitações sociais, em larga escala, e de forma dissociada de uma política de gestão e de terras urbanas, tendo como consequência, a exclusão social com a segregação e os ganhos fundiários por parte do setor privado imobiliário.

Essa utilização dos fundos públicos, por parte do Poder Público, para o Programa Minha Casa Minha Vida faz com que o setor privado imobiliário (especialmente as construtoras), se beneficiem dos subsídios públicos, além de canalizar esses recursos para a produção/acumulação capitalista, fazendo com que haja o crescimento das construtoras desse setor que transbordam os investimentos públicos para outros setores do mercado.

Nesse sentido, o PMCMV dá prioridade para que os investimentos imobiliários sejam feitos pelo Poder Público em áreas com infraestrutura, transporte coletivo, escolas, creches, postos de saúde. Entretanto, segundo as pesquisas analisadas, na prática, o que se detecta, é o deslocamento da população carente para a periferia, sem acesso a esses serviços públicos, mínimo necessário para todos os cidadãos. O que se faz na verdade é, primeiro construir o condomínio, criando a moradia, para depois investir nesses serviços. 
Um dos responsáveis por isso é o Município onde o condomínio foi construído, que é o gestor do uso e ocupação do solo, como também garantidor da aplicação dos instrumentos urbanísticos para efetivar esse direito fundamental à moradia, que, como vimos anteriormente, os municípios são negligentes na regulamentação e aplicação desses instrumentos.

O programa baseia-se na ideia de casa como mercadoria, e não como um direito fundamental efetivado pelo próprio Estado, uma vez que adota um modelo padrão nas construções, desvinculados dos instrumentos urbanísticos e dos direitos à cidade. Outra consequência é a segregação gerada pelo programa, uma vez que o espaço urbano é definido pela dinâmica social e sua estrutura é determinada em nível econômico, político-institucional e ideológico.

No que pertine às moradias construídas pelo programa, as pesquisas evidenciaram (2015), que as casas têm uma tecnologia voltada à otimização da construção, com a montagem rápida e padrão. Por outro lado, do ponto de vista arquitetônico, percebeu-se que as casas construídas pelo PMCMV são idênticas, com péssima arquitetura e baixa qualidade nos materiais utilizados.

Entretanto, a forma como são construídos os condomínios de casas e apartamentos desse programa se dá de forma fechada e murada, fragmentada e desconexa, o que os tornam sem qualificação. Na contramão, o programa gera a despolitização da questão da moradia, uma vez que, muitas vezes, os beneficiários das moradias são escolhidos não de forma transparente, mas através de relações privadas, baseadas na amizade ou parentesco.

Por tudo isso conclui-se que as moradias construídas pelo PMCMV são produzidas com uma arquitetura ruim; sem qualificação das áreas dos empreendimentos; com construções habitacionais desvinculadas das características físicas e climáticas locais; em condomínio com localizações ruins; sem um transporte coletivo eficaz; faltando infraestrutura urbana e serviços públicos; não possuindo transparência na seleção dos beneficiários das moradias; trazendo benefícios financeiros para o setor privado imobiliário; desvinculadas da política urbana e fundiária de cada município e, por fim, desarticuladas com as realidades locais.

Por fim, a abordagem crítica contra o PMCMV não tira o mérito do seu ato de enfrentar, em larga escala, o déficit habitacional no Brasil, mas, não se pode deixar de perceber que essa política patrimonial, realizada pelo suposto Estado do bem-estar social, através da ação do Estado, é direcionada aos interesses privados; como também, identificar a negligência dos Municípios na aplicação dos instrumentos urbanísticos, ocasionando os entraves ao programa pelo próprio direito; tudo isso, para atender o mercado financeiro e imobiliário, ou seja, 
defende-se neste artigo a tese que os obstáculos relativos à concretização do direito social à moradia são ocasionados pelo próprio Estado e pelo direito.

\section{REFERÊNCIAS BIBLIOGRÁFICAS}

ANDRADE, Diogo de Calasans Melo. O Princípio da Função Social da Propriedade. São Paulo: Letras Jurídicas, 2014.

AZEVEDO, Sérgio; ANDRADE, Luís Aureliano Gama de. Habitação e poder: da Fundação da Casa Popular ao Banco Nacional Habitação [online]. Rio de Janeiro: Centro Edelstein de Pesquisas Sociais, 2011.

BARBOSA, Jorge Luiz. As favelas na reconfiguração territorial da justiça social e dos direitos à cidade. In CARLOS, Ana Fani Alessandri; ALVES, Glória; PADUA, Rafael Faleiros (Orgs). Justiça Espacial e o Direito à Cidade. São Paulo: Contexto, 2017.

BONDUKI, Nabil. Política habitacional e inclusão social no Brasil: revisão histórica e novas perspectivas no governo Lula. In: Ivo Dickmann; Ivanio Dickmann. (Org.). A questão da habitação popular. Curitiba: Base Editorial, IBEP, 2015.

Do Projeto Moradia ao Programa Minha Casa. Revista Teoria e Debate 82, maio/junho 2009.

BONDUKI, Nabil; ROSSSETO, Rossella. O Plano Nacional de Habitação e os recursos para financiar a autogestão. Scripta Nova (Barcelona), v. x, p. x, 2008

CARDOSO, Adauto Lucio; MELLO, Irene de Queiroz e; JAENISCH, Samuel Thomas; GRAZIA, Grazia de. A retomada das remoções na cidade do Rio de Janeiro e o Programa Minha Casa Minha Vida. In CARDOSO, Adauto Lucio Cardoso; ARAGÃO Thêmis Amorim; JAENISCH, Samuel Thomas Jaenisch. Vinte e dois anos de política habitacional no Brasil: da euforia à crise. Rio de Janeiro: Letra Capital: Observatório das Metrópoles, 2017. 
CARLOS, Ana Fani Alessandri. A privação do urbano e o "direito à cidade" em Henri Lefebvre". In CARLOS, Ana Fani Alessandri; ALVES, Glória; PADUA, Rafael Faleiros (Orgs). Justiça Espacial e o Direito à Cidade. São Paulo: Contexto, 2017.

CASTELLS, Manuel. A questão urbana. Tradução: Arlene Caetano. 6a ed. São Paulo: Paz e Terra, 2014.

DEÁK, Csaba. Em busca das categorias do espaço. São Paulo: Annablume, 2016.

DOUZINAS, Costas. O Fim dos Direitos Humanos. São Leopoldo: Unisinos, 2009.

ENGELS, Friedrich. Sobre a questão da moradia. Tradução: Nélio Schneider. São Paulo: Boitempo editorial, 2015.

FERREIRA, João Sette Whitaker. Memorial circunstanciado. Concurso público de títulos e provas para provimento de dois cargos de professor titular, em RDIDP, referência ms-6, cargos/claros códigos № So 220345 e 152781. / Edital ATAC 063/2016, AUP FAUUSP, março de 2017. Cedido pelo próprio autor.

Minha Casa, Minha Vida: notas sobre a responsabilidade coletiva de um desastre urbano. Anais do XVI ENANPUR, Belo Horizonte, 2015.

Minha Casa, Minha Vida: notas sobre a responsabilidade coletiva de um desastre urbano. Anais do XVI ENANPUR, Belo Horizonte, 2015.

Produzir casas ou construir cidades? Desafios para um novo Brasil urbano. São Paulo: LABHAB, FUPAM, 2012.

GOTTDIENER, Mark. A produção social do espaço urbano. 2a ed. São Paulo: Edusp, 2016.

KRAUSE, Cleandro; BALBIM, Renato; NETO, Vicente Correia Lima. Minha Casa Minha Vida, nosso crescimento: Onde fica política habitacional? Texto para discussão/Instituto de Pesquisa Econômica Aplicada. Brasília: Rio de Janeiro: Ipea, 2013.

FROTA, Henrique Botelho. Função social da propriedade: pesquisa analisa aplicação de instrumentos urbanísticos. Publicado no 
siteObservaSPhttps://observasp.wordpress.com/2015/11/10/funcao-social-da-propriedadepesquisa-analisa-aplicacao-de-instrumentos-urbanisticos, em 10 de novembro de 2015, acessado em 22/09/2017.

MARICATO, Ermínia. Por um novo enfoque teórico na pesquisa sobre habitação. Revista cadernos metrópole 21, 10 sem. 2009.

O Ministério das Cidades e a política nacional de desenvolvimento urbano. Ipea. Políticas sociais - acompanhamento e análise, 12, fev. 2006.

Brasil, cidades: alternativa para a crise urbana. 2aㅡ ed. Petrópolis: RJ, 2002.

MARX, Karl. Os despossuídos: debates sobre a lei referente ao furto de madeira. Tradução de Karl Marx: Nélio Schneider, tradução de Daniel Bensaid: Mariana Echalar. São Paulo: Boitempo, 2017.

MIKE, Davis. Planeta Favela. Tradução: Beatriz Medina. São Paulo: Boitempo, 2006.

OLIVEIRA, Julio Cezar Pinheiro de. As dimensões corporativas do Programa Minha Casa Minha Vida: o dilema do limite entre política social e política econômica. In CARDOSO, Adauto Lucio Cardoso; ARAGÃO Thêmis Amorim; JAENISCH, Samuel Thomas Jaenisch. Vinte e dois anos de política habitacional no Brasil: da euforia à crise. Rio de Janeiro: Letra Capital: Observatório das Metrópoles, 2017.

PACHUKANIS, Evguiéni B. Teoria Geral do Direito e Marxismo. Tradução: Paula Vaz de Almeida; revisão técnica Alysson Leandro Mascaro, Pedro Davoglio. São Paulo: Boitempo, 2017.

PEREIRA, Luiz Ismael; BALCONI, Lucas Ruiz. Direito econômico e políticas sociais: impacto econômico do Programa Minha Casa Minha Vida. In DUARTE, Clarice Seixas Duarte et al. (orgs). Reflexões acadêmicas para superar a miséria e a fome. Bauru, SP: Canal 6, 2016.

RIZEK, Cibele Saliba; CAIO, Santo Amore; CAMARGO, Camila Moreno de. Política habitacional e políticas sociais: urgências, direitos e negócios. In Ana Fani Alessandri Carlos, Danilo Volochko, Isabel Pinto Alvarez (orgs). A cidade como negócio. São Paulo: Contexto, 2015. 
ROLNIK, Raquel; CYMBALISTA, Renato; NAKANO Kazuo. Solo urbano e habitação de interesse social: a questão fundiária na política habitacional e urbana do país. Revista de Direito da ADVOCEF. Porto Alegre, ADVOCEF, v.1, n.13, 2011

ROLNIK, Raquel. Prédios vazios, cumpra-se a lei! Blog da Raquel Rolnik https://raquelrolnik.wordpress.com/2014/11/03/predios-vazios-cumpra-se-a-lei/, publicado em 13/11/2014 e acessado em 22/09/217.

Democracia no fio da navalha limites e possibilidades para a implementação de uma agenda de reforma urbana no brasil. Revista Brasileira de Estudos urbanos e regionais, v. 11, n. 2, novembro 2009

SANTOS, Milton. A urbanização brasileira. 5aed. Editora da Universidade de São Paulo, 2013.

SHIMBO, Lúcia Zanin; A forma de produção da habitação social de mercado no Brasil. In CARDOSO, Adauto Lucio Cardoso; ARAGÃO Thêmis Amorim; JAENISCH, Samuel Thomas Jaenisch. Vinte e dois anos de política habitacional no Brasil: da euforia à crise. Rio de Janeiro: Letra Capital: Observatório das Metrópoles, 2017.

RUSSO, Endyra de Oliveira. O que o indicador indica? O déficit habitacional no Brasil e as disputas em torno de sua elaboração, em meados dos anos 1990. In CARDOSO, Adauto Lucio Cardoso; ARAGÃO Thêmis Amorim; JAENISCH, Samuel Thomas Jaenisch. Vinte e dois anos de política habitacional no Brasil: da euforia à crise. Rio de Janeiro: Letra Capital: Observatório das Metrópoles, 2017.

VILLAÇA, Flávio. Uma contribuição para a história do planejamento urbano do Brasil. In DEÁK, Csaba; SCHIFFER, Sueli Ramos (Org). O processo de urbanização no Brasil. 2ed, São Paulo: editora: edusp, 2015.

VOLOCHKO, Danilo. A Reprodução do Espaço Urbano como Momento da Acumulação Capitalista. In CARLOS, Ana Fani Alessandri (Org). Crise Urbana. São Paulo: Contexto, 2015.

Trabalho enviado em 04 de abril de 2018

Aceito em 26 de junho de 2018 